\title{
La exculpación como criterio punitivo frente a delitos conexos a la rebelión en contextos de conflicto armado interno: una relectura del quehacer del derecho penal en procesos de pacificación \\ Exculpation as a punitive criteria against crimes related to rebellion in contexts of internal armed conflict: A rereading of the criminal law work in pacification processes
}

\author{
JAIRO ENRIQUE LUCERO PANTOJA* \\ Universidad de Talca (Chile)
}

Resumen: Uno de los escenarios de mayor conflictividad existente para el derecho penal y sus respuestas sancionatorias y prevencionistas se encuentra en la confluencia de conflictos armados, siendo estos un motor inagotable de producción de actos delictivos regulados tanto a nivel nacional como internacional. El presente trabajo centrará su estudio en aquellos delitos conexos a los conflictos armados internos y en cómo podemos arribar a una lógica jurídica de mayor integralidad desde una perspectiva dogmática penal derivada de la teoría del delito —-más que una respuesta política cimentada en la amnistía-, específicamente a través de los estados de necesidad, al momento de brindar resolución definitiva a un contexto de conflicto armado, lo cual exige soluciones penales no limitadas a las fronteras dialécticas de cada gobierno de turno.

Palabras clave: estado de necesidad justificante, estado de necesidad exculpante, delitos conexos al conflicto armado interno, nivel de preponderancia, justicia transicional, atenuación sancionatoria

\begin{abstract}
One of the most conflictive scenarios for criminal law and its punitive and preventive responses is found at the confluence of armed conflicts, being these an inexhaustible engine of production of regulated criminal acts, both nationally and internationally. The present work will focus its study on those crimes related to internal armed conflicts and on how we can reach a more comprehensive legal logic from a dogmatic criminal perspective derived from the theory of crime - more than a political response in amnesty-, specifically through assumptions of need, when providing a definitive resolution to a context of armed conflict, which requires unrestricted criminal solutions to the dialectical borders of each government in office.
\end{abstract}

\footnotetext{
* Abogado de la Facultad de Derecho y Ciencias Políticas de la Universidad de Nariño (Colombia), especialista en Derecho Ambiental por la Universidad de Buenos Aires (Argentina), magíster en Derecho Ambiental por la Universidad de Palermo (Argentina) y doctorando en Derecho por la Universidad de Talca (Chile).

Código ORCID: 0000-0001-7656-3641. Correo electrónico: jlucero@utalca.cl
} 
Key words: Grounds of justification, assumptions of justifying need, assumptions of exculpating need, crimes related to the internal armed conflict, level of prevalence, transitional justice, sanction mitigation

\begin{abstract}
CONTENIDO: I. INTRODUCCIÓN.- II. DELIMITACIÓN DE CONTEXTOS Y DELITOS DE CONFLICTO FRENTE AL ACTUAR EXCULPATORIO.- III. UNA ACLARACIÓN DEL PANORAMA: UBICANDO LA EXCULPACIÓN EN EL MAPA DE LA TEORÍA DEL DELITO.- III.1. RESOLVIENDO ALGUNOS DILEMAS.IV. JUSTIFICACIÓN DE LA APLICABILIDAD DEL ESTADO DE NECESIDAD EXCULPANTE EN CONTEXTOS DE CONFLICTO ARMADO Y SU IMPORTANCIA EN EL ANDAR CIENTÍFICO DEL DERECHO PENAL.- IV.1. PROPUESTA.- V. LOS BACHES EN LA PROPUESTA.- VI. PALABRAS FINALES.
\end{abstract}

\title{
I. INTRODUCCIÓN
}

Los conflictos sociales de carácter armado son tal vez los espacios temporales en los que se vulneran en mayor medida las circunstancias típicas de innumerables sujetos de derechos y, también — posteriormente a estas violaciones-, la fuente de mayor productividad en creación jurídico-penal para la protección de esos mismos derechos de seguridad, debido proceso y paz social que fueron tan vulnerables durante la confrontación armada.

Así las cosas, haciéndose cargo de la teoría comunicativa de la pena en contextos de justicia transicional, Accatino (2019, pp. 49-50) establece la necesidad de que los perpetradores de un delito sean categorizados de esa manera, con el objetivo de que el delito no desnaturalice su contenido delictual. Además, hace hincapié en que estos respondan jurisdiccionalmente a fin de ser sometidos — si son vencidos en juicio- a una pena retributiva (lo cual es modulable a partir de una justicia especial posacuerdos de paz), dado que solo de esta manera se reflejan los agravios (wrongdoings) que requieren una «respuesta formal y pública, de censura o condena», y con ello posibilitar unísonamente la «lucha contra la impunidad como la preservación del orden jurídico» (Rúa, 2020, p. 124).

No obstante lo anterior, ha sido amplia la práctica del uso de la amnistía y el indulto como instrumentos que potencian la pacificación de los conflictos armados, dejando su ejecución —en la mayoría de casos—a las libres deliberaciones políticas que los gobiernos de turno sustentan y aplican subjetivamente (Lucero, 2012, pp. 22-30). En ese sentido, es de interés notar la flexibilidad de los estándares que limitan dichos armisticios, los cuales dependen tanto de la rigurosidad con que se acojan los criterios internacionales de derecho internacional humanitario y 
las graves violaciones de derechos humanos como de los instrumentos internacionales suscritos por el país en referencia ${ }^{1}$.

Es en esta medida que, usando el elemento de exculpación propio de la culpabilidad, abordaremos su practicidad en escenarios de posacuerdos derivados de conflictos armados internos, tratando de eliminar con esto la variación política que pueda afectar los procesos de justicia transicional. Para ello, como primera medida, será necesario precisar en qué tipos penales surcaremos su aplicabilidad, para luego debatir la posibilidad del encuentro de soluciones a partir de la figura justificante del estado de necesidad (EN) y, finalmente, proponer el uso del estado de necesidad exculpante como mejor medida de resolución de los denominados «delitos conexos» en conflictos armados internos, siendo el razonamiento científico y garantista del derecho penal la respuesta en escenarios transicionales por sobre decisiones políticas coyunturales $-\mathrm{y}$ peligrosamente esquizofrénicas ${ }^{2}$ -

\section{DELIMITACIÓN DE DELITOS FRENTE AL ACTUAR EXCULPATORIO}

Con el fin de brindar los parámetros de nuestro análisis frente a la respuesta de la teoría del delito - y más específicamente desde la culpabilidad y el estado de necesidad exculpante-, daremos pie a la delimitación de los acontecimientos fácticos de los conflictos armados que pretendemos acoplar en este estudio.

En primera medida, es necesario precisar que todos los conflictos armados internos parten de un margen jurídico internacional de respeto; esto es, un orden normativo para ejercer la guerra o, como se ha denominado, el ius bellum. Si bien esto es cierto desde la estructuración de la Organización de las Naciones Unidas y la Declaración de los Derechos Humanos como prismas institucional y normativo, respectivamente, que

LA EXCULPACIÓN

COMO CRITERIO

PUNITIVO FRENTE A

DELITOS CONEXOS

A LA REBELIÓN

EN CONTEXTOS

DE CONFLICTO

ARMADO INTERNO:

UNA RELECTURA

DEL QUEHACER DEL

DERECHO PENAL

EN PROCESOS DE

PACIFICACIÓN

EXCULPATION

AS A PUNITIVE

CRITERIA AGAINST

CRIMES RELATED

TO REBELLION

IN CONTEXTS OF

INTERNAL ARMED

CONFLICT: A

REREADING OF

THE CRIMINAL

LAW WORK IN

PACIFICATION

PROCESSES

1 Ejemplo de ello es cómo la Corte Constitucional colombiana, haciendo referencia a este vacío, señala que «La ausencia de parámetros en la materia estudiada, lejos de ser contraproducente, se considera positiva, en tanto crea un margen de apreciación del Estado que le permite adaptar su regulación a las específicas necesidades que pueden surgir en los procesos que, en pos de un objetivo como la paz, requieran la adopción de marcos de justicia transicional, en los que siempre jugará un papel protagónico la reconciliación" (Sentencia C-577, 2014). Sin embargo, el peligro no observado por la Corte, y del que queremos hacernos cargo en el presente artículo, es justamente la falta de eficacia que puede tener una perspectiva política trasformada por un gobierno de turno diferente al que inició un acuerdo de transición. Por ello la necesidad de instrumentos jurídico-penales coherentes con las garantías político-criminales y superadores de coyunturas meramente gubernamentales, más aún cuando el objetivo buscado es la pacificación social.

2 Bien hacía referencia Jakobs $(2008$, p. 22) al decir que el objetivo de la ciencia de la dogmática penal es «dar respuesta a la pregunta acerca de cuál Derecho penal es legítimo en una época determinada y cuál no lo es", no obstante no significando esto que la misma pueda ser remplazada al albedrío subjetivo de una persona o una institución, pues esto requiere un nivel elevado de compenetración con los conflictos fácticos a los que se dirige, y un igualmente elevado estándar de motivación para darle coherencia y sistematicidad a la respuesta político-criminal (constructos teórico-metodológicos llamados paradigmas por Schurmann [2019, pp. 556 y ss.]), aun —o mejor, mucho más—cuando es de carácter excepcional. 
tienen como fin la paz mundial (Hobsbawm, 2007, p. 179), no es menos cierto que ambas coinciden en la casi irrenunciabilidad del conflicto ${ }^{3}$, el cual, si bien podría ser considerado como prácticamente connatural al ser humano, debe cumplir con un marco jurídico establecido para ser legitimado (Travesí \& Rivera, 2016, p. 2). Es así que en 1949 se establecieron los Convenios de Ginebra como un compilatorio histórico de cuatro tratados precedentes ${ }^{4}$, siendo necesario para esta época establecer artículos trasversales a todos los convenios, y principalmente a tres: a) el compromiso de «respetar y a hacer respetar» todos los convenios, b) la obligatoria aplicación de los convenios en conflictos de carácter internacional — valga decir, en los que participe uno o varios Estados contratantes-, y c) la obligatoria aplicación de los convenios en conflictos de carácter interno - es decir, en aquellos generados dentro de un Estado contratante-, precisándose que la aplicación de las disposiciones deberá ser cumplida por ambas partes en conflicto: el Estado y la «organización insurrecta».

Ahora bien, este último artículo, cuyo objetivo común es ampliar las garantías establecidas por los Convenios de Ginebra a los conflictos de carácter interno, tuvo su origen en la preocupación constante por consagrar condiciones mínimas relativas a confrontaciones nacionales, sobre todo de carácter social conciudadano ${ }^{5}$, preocupación que encontraría un nuevo pico una década después de firmados los convenios, pues coyunturas como la latinoamericana y africana —en las que se perpetraron diversas guerras civiles, derrocamientos de gobiernos autoritarios, imposición de dictaduras y, finalmente, enfrentamientos constantes con organizaciones alzadas en armas, cesionistas o rebeldes - marcaron la necesidad de complementar las disposiciones firmadas en 1949 en Suiza. Ello posibilitaría, posteriormente, que las normas por las que se rige un conflicto armado internacional sean incluso «menos elaboradas que las normas por las que se rige el conflicto armado no internacional» (Trejos, 2011, p. 133).

3 Basta observar el Preámbulo de la Declaración Universal de los Derechos Humanos de 1948, donde se expresa: «Considerando esencial que los derechos humanos sean protegidos por un régimen de Derecho, a fin de que el hombre no se vea compelido al supremo recurso de la rebelión contra la tiranía y la opresión».

4 En tal sentido, los Convenios de Ginebra unifican a) el convenio de Ginebra para el mejoramiento de la suerte que corren los militares heridos en los ejércitos en campaña de 1864 (Primera Convención de Ginebra), el cual fue actualizado en 1929 y 1949; b) el Convenio de Ginebra para el mejoramiento de la suerte de los militares heridos, enfermos o náufragos en las fuerzas armadas en el mar de 1906 (Segunda Convención de Ginebra), actualizado en 1929 y 1949; c) el Convenio de Ginebra para mejorar la suerte de los heridos y enfermos de los ejércitos en campaña y el Convenio de Ginebra relativo al trato de los prisioneros de guerra, firmados en 1929 y actualizados en 1949 (Tercera Convención de Ginebra); y, finalmente, d) el Convenio de Ginebra relativo a la Protección de Personas Civiles en Tiempo de Guerra, de 1949 (Cuarta Convención de Ginebra). Al respecto, ver Comité Internacional de la Cruz Roja (2010).

5 Es interesante recordar que ya en 1758, en su obra Derecho de Gentes o Principios de Derecho Natural, Emmer de Vattel «planteó por primera vez el problema de si el soberano debe observar las leyes ordinarias de la guerra para con los súbditos rebeldes que han tomado abiertamente las armas contra él» (Bustos, 2004, pp. 68-69), tratando de encontrar una respuesta normativa de reglas de guerra. 
De esta forma, en el año de 1977 se adoptaría en el seno de las Naciones Unidas dos protocolos de reforzamiento para los conflictos de carácter internacional (Protocolo I) y nacional (Protocolo II). Asimismo, este último establecería en su artículo 1:

1. [...] se aplicará a todos los conflictos armados [...] que se desarrollen en el territorio de una Alta Parte contratante entre sus fuerzas armadas y fuerzas armadas disidentes o grupos armados organizados que, bajo la dirección de un mando responsable, ejerzan sobre una parte de dicho territorio un control tal que les permita realizar operaciones militares sostenidas y concertadas y aplicar el presente Protocolo.

2. El presente Protocolo no se aplicará a las situaciones de tensiones internas y de disturbios interiores, [...] que no son conflictos armados.

Con esto precisado, se deben analizar tres elementos fundamentales con los cuales determinaremos la existencia de un conflicto armado interno, a saber: a) el conflicto debe generarse en el territorio de una parte firmante de los Convenios de Ginebra y sus respectivos protocolos, b) la organización insubordinada al mandato estatal debe poseer una estructura que permita visibilizar el responsable de mando de sus acciones, y c) dicha organización debe obtener un control territorial reflejado en actividades militares con dos características: sostenidas en el tiempo y concertadas con su estructura de mando.

En primera medida, es necesario recordar que el alcance de los Convenios de Ginebra y sus Protocolos —a los que denominaremos derecho internacional humanitario (DIH) — tienen una aplicación universal $^{6}$ debido a la ratificación absoluta de estos instrumentos por parte de todos los países, siendo solo obstáculo para su aplicación el incumplimiento de los elementos antes señalados en el numeral 1 del primer artículo del Protocolo II de los Convenios de Ginebra ${ }^{7}$. Por otro

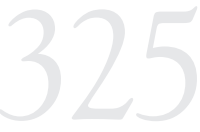

LA EXCULPACIÓN COMO CRITERIO

PUNITIVO FRENTE A DELITOS CONEXOS

A LA REBELIÓN

EN CONTEXTOS

DE CONFLICTO

ARMADO INTERNO:

UNA RELECTURA

DEL QUEHACER DEL

DERECHO PENAL

EN PROCESOS DE

PACIFICACIÓN

EXCULPATION

AS A PUNITIVE

CRITERIA AGAINST

CRIMES RELATED

TO REBELLION

IN CONTEXTS OF

INTERNAL ARMED

CONFLICT: A

REREADING OF

THE CRIMINAL

LAW WORK IN

PACIFICATION

PROCESSES

6 Desde su entrada en vigor el 21 de octubre de 1950, los Convenios de Ginebra fueron ratificados paulatinamente a lo largo de las décadas: en 1950 los ratificaron 74 Estados, en 1960 fueron 48, en la década de 1970 fueron 20, otros 20 en 1980 y 26 Estados a comienzos de 1990, justo después de la disolución de la Unión Soviética, Checoslovaquia y la antigua Yugoslavia. Por último, 7 nuevas ratificaciones se dieron en el 2000, aumentando el total de Estados partes de los Convenios de Ginebra a 194 y convirtiendo así su alcance en universal (Comité Internacional de la Cruz Roja, 2010).

7 No obstante, es meritorio considerar que frente al conflicto armado colombiano sostenido con las fuerzas beligerantes por más de medio siglo, el Gobierno nacional recurrió a la falta de reconocimiento de estatus político de las organizaciones ilegales que combatía, hecho que - según dicha postura- devenía en la falta de aplicabilidad de las garantías establecidas en el DIH. No obstante, en numerosas ocasiones la Cruz Roja Internacional, la Comisión de Derechos Humanos de la ONU y la Corte Interamericana de Derechos Humanos han insistido en que el factor de reconocimiento o no del estatus político de la organización beligerante no omite la responsabilidad del Estado de cumplir los mínimos enmarcados en el DIH, por lo que resulta evidente precisar que el reflejo político o perspectiva del Estado (o gobierno de turno) ante el conflicto no omite la obligatoriedad del marco normativo internacional (Trejos, 2011, p. 138). Finalmente, también es interesante aclarar que el último extracto del artículo 3 común, «La aplicación de las anteriores disposiciones no surtirán efecto sobre el estatuto jurídico de las Partes en conflicto", se ciñe a la inmodificabilidad del reconocimiento de personería jurídica que un Estado brinda hacia el grupo armado beligerante, por lo que la aplicación del DIH no es un subrogado a dicho grupo, sino 
lado, de comprobarse dicha ausencia, solo será exigido el efectivo cumplimiento de la normativa contenida por el derecho internacional de los derechos humanos (Trejos, 2008, p. 2).

Aclarado lo anterior, nos encontramos ante el siguiente panorama. Dentro de un conflicto armado interno podemos vislumbrar, además de las hostilidades permitidas por el marco de guerra internacional de Ginebra, tres grandes conjuntos de delitos: a) aquellos atentatorios del DIH; b) los delitos frente al Sistema Internacional de los Derechos Humanos; y, finalmente, c) aquellos delitos conexos al conflicto, con lo cual, claro, dejamos de lado aquellos producidos sin ocasión al desarrollo del conflicto8.

En tal sentido, nuestra propuesta desde la teoría del delito a partir de los estados de necesidad se basará única y exclusivamente en los delitos conexos a los conflictos armados internos, dado que para el resto existe un particular marco normativo de observación internacional ${ }^{9}$. En el caso de los delitos remanentes, estos con frecuencia quedan en su vacío a disposición de la política penal interna del Estado en cuestión, generando con ello no solo mayores problemáticas jurídicas (cuyo origen es meramente político) frente a un posible escenario de pacificación, sino también la pérdida de la seguridad jurídica que el Estado debe garantizar a todo el conjunto de ciudadanos de su territorio, aun cuando estos sean combatientes de una organización ilegal en insubordinación estatal ${ }^{10}$.

una obligación del Estado para con sus ciudadanos y el resto de los Estados partes de los Convenios de Ginebra (Comité Internacional de la Cruz Roja, 2016, num. 20).

8 La Corte Interamericana de Derechos Humanos ha precisado en sentencias como Masacre de Santo Domingo vs. Colombia (2012) que el DIH debe ser aplicado «en el marco de conflictos armados no internacionales, siempre y cuando los hechos correspondan a situaciones que se producen con ocasión y en desarrollo del conflicto» (nota al pie 254), aun cuando bien precisan Travesí y Rivera (2016, pp. 15-16) la complejidad de dicha determinación, siempre que existen «zonas grises» en el análisis fáctico e intencional de los objetivos o en función (o en ocasión) de qué se realizaban dichos ilícitos.

9 Es trascendente recordar el marco jurisprudencial establecido por la Corte Interamericana de Derechos Humanos frente al tratamiento de ilícitos contemplados en el DIH o que constituyen graves violaciones al DIDH. De tal forma, en las «leyes de autoamnistía» (Caso Barrios Altos vs. Perú, 2001, $\S$ 41; Caso Almonacid Arellano vs. Chile, 2006) son inadmisibles las disposiciones que impidan la investigación y sanción de los responsables de dichos ilícitos (entre ellas la «tortura, las ejecuciones sumarias, extralegales o arbitrarias y las desapariciones forzadas»), deberes que la misma Corte considera normas ius cogens. En el mismo sentido, frente a las «leyes de amnistía generales», las considera «inadmisibles [cuando] pretendan impedir la investigación y sanción de los responsables de las violaciones graves de los derechos humanos" (Caso Gomes Lund y otros vs. Brasil, 2010, § 175), aun cuando estas tengan como base procesos plebiscitarios (Caso Gelman vs. Uruguay, 2011, § 239). Por último, ya dentro del terreno de procesos de justicia transicional, la Corte proyecta una flexibilidad ante los ilícitos atentatorios al DIDH, no queriendo decir con ello que no vulneran el contenido de la Convención Americana de Derecho Humanos, sino que al tratarse de «hechos cometidos en el contexto de un conflicto armado", es deber - como un parámetro mínimo- investigar y sancionar «al menos las graves violaciones de derechos humanos que estableciera la Comisión de la verdad, de modo tal que no quedaran impunes y evitara su repetición» (Caso Masacres de El Mozote y Lugares Aledaños vs. El Salvador, 2012). Para un acercamiento profundo a dicha línea jurisprudencial interamericana, ver Gómez Velásquez (2016, pp. 155-158).

$10 \mathrm{La}$ tensión entre derecho y justicia es de larga data, teniendo su punto de inflexión a finales de la segunda mitad del siglo XX, cuando se sopesa el positivismo que privilegió la seguridad jurídica del gobierno nacionalsocialista alemán frente a las prácticas atentatorias a la dignidad humana desarrolladas por este, las cuales son legales aunque injustas (Rúa, 2020, p. 132). Ahora bien, esto no quiere decir que se deplora el contenido, especialmente del principio de legalidad, en un sistema 
Así, concebiremos como delitos conexos a aquellos devenidos del primigenio acto delictual de contenido político; valga aclarar, la rebelión, de cuya insubordinación se desprenderán otros actos delictuales que soportarán el fin o el objetivo del tipo principa ${ }^{11}$. De tal forma, el delito conexo está motivado por un móvil y de ello depende su categoría, sin que deje de ser un delito principal en esencia, por lo que Nazir (2015) precisará que este «se realiza concomitantemente al delito político, que no se surte con actuaciones aisladas, requiriendo [por tanto] un mínimo de organización» (p. 41). Ahora bien, debemos considerar que el desarrollo de un delito político como la rebelión nunca se presenta como un delito político puro, pues necesariamente requiere de otros actos para perfeccionarse y conservar su condición, siendo cada uno de estos elementos nuevos actos también tipificados. Es por este motivo que Luis Carlos Pérez (1986) precisaría que:

el delito político puro es una ilusión pura. Nadie se levanta en armas para que estas permanezcan en alto. [...] De sus explosiones depende el sojuzgamiento o la liberación. Cualquiera que sea el daño resultante, como este encadenado al objetivo propuesto, es un daño que se vincula al hecho principal. La culpabilidad se unifica. No hay tantas infracciones como bienes jurídicos afectados sino una sola: la política. Con las excepciones que expresamente señale la ley (p. 132).

Con esto señalado, consideraremos como delitos conexos los de porte ilegal de armas, extorsión, financiación u ocultamiento de actividades ilícitas, asonadas y afines, sin descartar otros delitos de mayor relieve jurídico $^{12}$, como el narcotráfico ${ }^{13}$ y el terrorismo ${ }^{14}$, decisión que

jurisdiccional, sino que en un escenario de justicia transicional, con el fin de cumplir el objetivo de pacificación social, las leyes — pasadas, entiéndase, de guerra- pueden ser un obstáculo en el camino hacia este horizonte (y de ahí la necesidad de su flexibilización) en la misma medida en que el cambio de paradigma de justicia de acuerdo a la orientación política del gobierno de turno puede convertirse, al ser reglado en medio de dicho proceso posacuerdo, en un tropiezo jurídico arbitrario, arribando peligrosamente a actitudes punitivas autoritarias (Guzmán, 2019, pp. 619 y ss.).

11 El delito político, a diferencia de los «ordinarios», tiene como propósito el mejoramiento de la dirección de los intereses públicos (motivación supuestamente altruista) y, por tanto, no posee objetivos egoístas. Dentro de estos delitos se destaca prioritariamente el de rebelión, pero también es acompañado por los tipos penales de sedición, asonada, conspiración e incluso, la seducción, usurpación y retención ilegal del mando (Travesí \& Rivera, 2016, pp. 5-6).

12 Desde una tesis subjetiva del concepto de conexidad en la dogmática penal, y como bien lo afirma Bustos Ramírez (1991), "cualquier delito de los previstos en el código penal puede llegar a tener una motivación política», siendo necesario aclarar que el DIH es un límite irrefutable para esta subjetivización. También ver Nazir (2015, pp. 63-64).

13 Cabe recordar que en el proceso de paz colombiano, llevado por las instituciones gubernamentales y la guerrilla de las FARC-EP entre 2012 y 2018, el delito de narcotráfico se consideró un delito conexo al delito político de rebelión y, por tanto, concomitante al desarrollo del conflicto. No obstante, se debe advertir que esta consideración debió superar lo señalado por la Convención de las Naciones Unidas contra el tráfico ilícito de estupefacientes y sustancias psicotrópicas de 1988, cuyo artículo 3 , numeral 10, señala la imposibilidad de establecer los delitos relacionados al tráfico de estupefacientes con fines de comercialización exterior como «delitos fiscales o como delitos políticos ni como delitos políticamente motivados, sin perjuicio de las limitaciones constitucionales y de los principios fundamentales del derecho interno de las Partes». La permisión colombiana se fundó en la última consideración.

14 Es pertinente precisar la existencia en diversos ordenamientos nacionales de diferentes conceptos de terrorismo, así como los delitos que este abarca, ello producto de la pluridiversidad de ámbitos en los

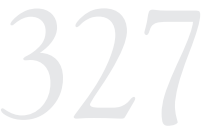

LA EXCULPACIÓN

COMO CRITERIO

PUNITIVO FRENTE A

DELITOS CONEXOS

A LA REBELIÓN

EN CONTEXTOS

DE CONFLICTO

ARMADO INTERNO:

UNA RELECTURA

DEL QUEHACER DEL

DERECHO PENAL

EN PROCESOS DE

PACIFICACIÓN

EXCULPATION

AS A PUNITIVE

CRITERIA AGAINST

CRIMES RELATED

TO REBELLION

IN CONTEXTS OF

INTERNAL ARMED

CONFLICT: A

REREADING OF

THE CRIMINAL

LAW WORK IN

PACIFICATION

PROCESSES 
finalmente tendrá una connotación política y, eventualmente, jurídica para su justificación (Travesí \& Rivera, 2016, p. 8) (ver figura 1).

Ahora bien, debemos observar en igual medida que esta aclaración de política criminal debe someterse necesariamente a un escenario que, además de contar con la existencia de un conflicto armado interno, confluya también en un proceso de paz - y, con ello, a la construcción de la justicia de transición ${ }^{15}$-, por lo cual los delitos conexos al conflicto cobran sentido al no ser sopesados con el conjunto analítico sancionatorio que desarrollarían los tribunales de justicia en tiempos de abierto combate armado, político y jurídico-penal, ya que en este escenario se convertirían en factores agravantes de la sanción y no como se quiere vislumbrar- en tipos huérfanos que en la coyuntura política de un proceso transicional pueden perjudicar y entorpecer el tratamiento jurídico propuesto por el proceso mismo.

\section{Figura $N^{\circ}$ 1. Tipicidad e ilicitud}

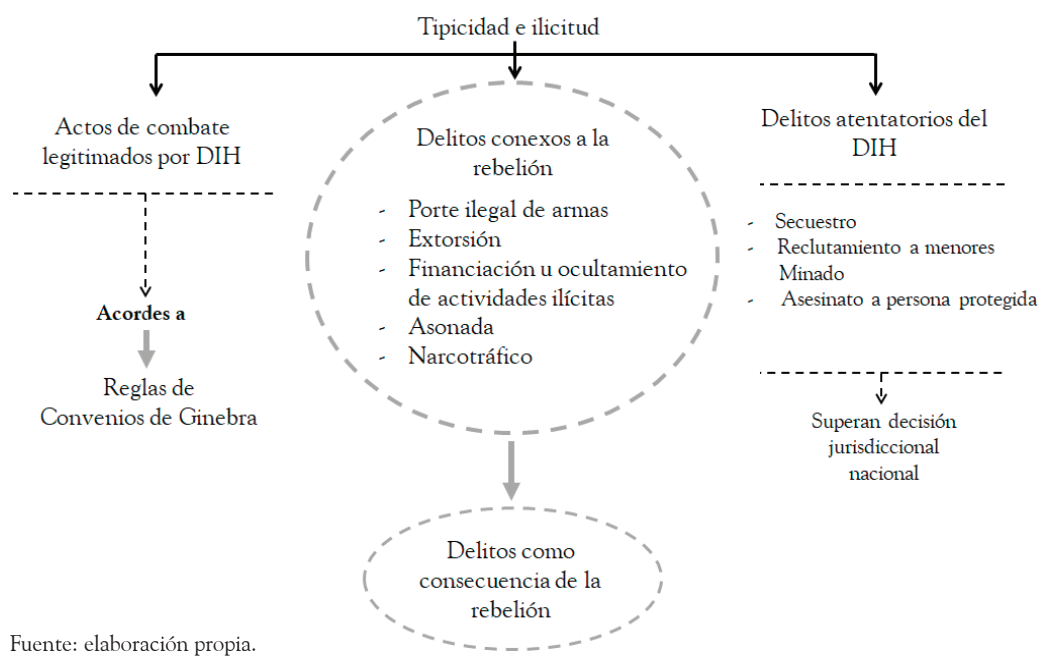

que este «tipo penal» se ha observado (esto desde el Convenio sobre las infracciones y ciertos otros actos cometidos a bordo de las aeronaves de 1963 hasta el Convenio internacional para la represión de los atentados terroristas cometidos con bombas de 1998). Por tanto, su mejor tratamiento proviene del Comité Internacional de la Cruz Roja (2011, p. 57), el cual señala la necesidad de especificar en qué momento se cometen dichos ilícitos: a) de llegar a ser en tiempos de guerra, estos esencialmente deben ser analizados en comparación con las infracciones al $\mathrm{DIH}$; mientras que b) si se ejecutan en tiempos de paz, «generalmente, constituyen un tipo penal que se ha ido ampliando progresivamente como resultado de doctrinas o decisiones políticas destinadas a descalificar a los adversarios no estatales llamándolos "terroristas"» (Travesí \& Rivera, 2016, p. 9). Así las cosas, entenderemos contemplados aquellos delitos conexos que, a pesar de ser tipificados como «terroristas», no infringen lo establecido por el DIH o presentan graves violaciones al DIDH.

15 A partir del relacionamiento jurídico entre la filosofía del derecho penal y la teoría de la democracia propuesta por Antony Duff (2014, p. 13), se hace permeable la idea de un sistema de justicia - siempre referente en lo penal- que aborde abusos jurídicamente relevantes del pasado puesto que, debido a la falta de eficacia institucional para resolverlos jurisdiccionalmente, es imprescindible un sistema transitorio (Gargarella, 2016, p. 165) que haga énfasis, a fin de su aplicabilidad y legitimidad, en la inclusión de la «reconstrucción de la verdad, la justicia, las reparaciones, las reformas institucionales que garanticen la no repetición y, también, en los últimos años, la memoria» (Accatino, 2019, pp. 48-50). 
Con esto precisado, comenzaremos la resolución de esta problemática a través de las herramientas del estado de necesidad exculpatoria y justificante presentes en la teoría del delito.

\section{UNA ACLARACIÓN DEL PANORAMA: UBICANDO LA EXCULPACIÓN EN EL MAPA DE LA TEORÍA DEL DELITO}

Cada uno de los avances teóricos existentes en materia penal devenidos en el último siglo halla sus bases en las necesidades irresueltas por las teorías causalistas en la teoría del delito, propias de Liszt y Beling ${ }^{16}$. Es de este modo que a través de Welzel (1964; 1968, pp. 223-225) y sus postulados de la «acción final» — que obligaban a observar la conducta humana más allá de un mero fenómeno causante de un resultado (Cerezo, 2009, pp. 83-85)—, el derecho penal se tornó desde la segunda mitad del siglo XX en una ciencia de análisis compartimentado entre la pragmática y el análisis de la voluntad y sus fines. La base para ello fueron las nuevas teorías de carácter funcionalista que, alejadas del causalismo, se cimentaron en la apertura a un «sistema social» que exige, a partir del estructuralismo, dar sentido a la identificación e interpretación de las formas de relación entre los componentes del objeto de conocimiento y, con esto, también a las relaciones del objeto en su contexto (Ramírez, 2016, p. 10; Pouillon, 1969, p. 22), siendo menester el estudio de cada categoría dentro del sistema ${ }^{17}$.

Ahora bien, superándose los avances de la tipicidad generados a partir del finalismo de Welzel, en donde la culpabilidad toma una suerte de vaciamiento del dolo y la culpa y estos se trasladan al tipo (ahora visualizado como objetivo y subjetivo), la antijuridicidad y la culpabilidad se vuelven los componentes que darán refinamiento a la teoría del delito como una práctica dogmática que posibilite la justa adecuación de la sanción a un hecho positivizado, comprobado como ilícito y confirmado como punible.

Dicho lo anterior, podemos considerar una perspectiva bifronte de la antijuridicidad: a) una en la que, a través de las tesis de Graf zu Dohna,

16 Fruto de la dogmática de Liszt radicada en el método analítico, y de Von Beling y su obra Die Lehre vom Verbrechen, surge un concepto definido de acción, ubicándolo como un «movimiento corporal que causa una modificación del mundo exterior». Como vemos, este movimiento, percibido desde la perspectiva naturalista por la influencia y auge de las ciencias naturales, es eminentemente "causado por un acto de voluntariedad" (valga decir, por un impulso de la voluntad) que produce un resultado, siendo ello el vehículo del razonamiento de causalidad. Es justo anotar como corolario a lo antedicho las palabras de Zielinski: «para la determinación de que existe una acción, basta la certeza de que el autor ha actuado voluntariamente. Que haya querido es aquí indiferente» (Gaitán, 2019).

17 Ejemplo de ello es cómo la pena, desde una perspectiva funcional, se contempla a través del reflejo del Sistema General del Derecho, en donde esta — como componente del segundo- se observa como un elemento de necesidad para la vigencia del sistema normativo (Jakobs, 1997, p. 12); o, en cambio, se proyecta como un mecanismo que tiene como fin la salvaguarda de los bienes jurídicos (Roxín, 1997, p. 41).

LA EXCULPACIÓN

COMO CRITERIO

PUNITIVO FRENTE A

DELITOS CONEXOS

A LA REBELIÓN

EN CONTEXTOS

DE CONFLICTO

ARMADO INTERNO:

UNA RELECTURA

DEL QUEHACER DEL

DERECHO PENAL

EN PROCESOS DE

PACIFICACIÓN

EXCULPATION

AS A PUNITIVE

CRITERIA AGAINST

CRIMES RELATED

TO REBELLION

IN CONTEXTS OF

INTERNAL ARMED

CONFLICT: A

REREADING OF

THE CRIMINAL

LAW WORK IN

PACIFICATION

PROCESSES 
Mayer, Hegler y Zimmerl (Schünemann, 1991, p. 50), se observa como una valoración de la acción típica, siendo un reflejo de la evaluación concurrente a la tipicidad (antijuridicidad formal) y a la dañosidad real del interés jurídicamente tutelado (antijuridicidad material) ${ }^{18}$; y b) aquella antijuridicidad que abarca las causas de justificación penal del injusto ${ }^{19}$, en donde la acción puede ser típica, pero justificada por el mismo ordenamiento jurídico —es decir, también lícita (Silva, 1992, pp. 398, 414)—, de tal suerte que la concurrencia de las causales de justificación genera la falta de perfeccionamiento del delito y, por ende, el reproche sancionatorio por la acción ${ }^{20}$.

Por su parte, la culpabilidad, para la gran mayoría de la doctrina penal (centrándonos en aquellas que excluyen de la teoría del delito la punibilidad), determina finalmente la posibilidad de ejercicio del ius puniendi, ello siempre que al autor de una acción típica y antijurídica tenga las características precisas que permitan proyectarle un reproche estatal o que, en otras palabras, pueda hacérsele responsable de las consecuencias de sus actos, todo esto bajo los criterios de la dignidad humana (Ovalle, 2019, pp. 48-49, 54; Bacigalupo, 2005, p. 112). Estas características dependerán en gran medida de la corriente doctrinaria que deseemos acoger y el desarrollo histórico en el que precisemos consolidar la culpabilidad (reconociéndola o no como categoría sistemática de la teoría del delito).

En este sentido, podemos abordar la culpabilidad en sus orígenes, durante la Baja Edad Media de los siglos XVI y XVIII, como responsabilidad derivada de la imputatio —Puffendorf-, para pasar a constituirla como el fundamento subjetivo de la punibilidad - Feuerbach-y, con ello, asimilarla a una «imputación subjetiva». Así, con la asunción de la culpabilidad como elemento sistémico jurídico-penal, esta se torna como un presupuesto del injusto - Jhering y Merkel—, generando con esto el estudio del dolo y la culpa en esta sede - Karl Binding - (Velásquez, 1993, p. 284). En este primer desarrollo doctrinal, se cimenta una postura psicologista que vislumbra el peligro generado por un acto típico como eje de estudio para brindar como resultado una sanción penal, relacionándose para ello (aunado el injusto cometido) una evaluación del grado «antisocial» del acto.

Estos retazos doctrinales permitirían finalmente consentir a la culpabilidad como la «contrariedad al deber», por lo que Liepmann la resaltaría como «un juicio de reprobación éticamente matizado»,

18 Integración de dicho paradigma a través del análisis sistemático del derecho penal bajo el influjo de neokantianismo. Ver Schünemann (1991, pp. 47-53).

19 Roxín (2002, pp. 8-20) encuentra en el concepto de «injusto penal» la conjunción de las tres primeras categorías de la teoría del delito, a saber: una acción, típica y antijurídica.

20 Es en esta medida que Figueiredo (2011, pp. 441-458) denomina al EN justificante como «derecho de necesidad". 
mediando «una actuación de la voluntad contraria al deber», o lo que posteriormente resolvería Beling como el «reproche que se formula a alguien por no haber actuado de otro modo» (Velásquez, 1993, p. 286).

Ahora bien, extraído el dolo y la culpa como formas de la acción (cuyo resultado en el juicio de reproche no tenía peso), y enfocando la culpabilidad como una valoración del objeto (Dohna, 1958, pp. 14, 40; Velásquez, 1993, p. 295) —más que el objeto de la valoración, que constituye el estudio del injusto-, Welzel dota de contenido material al juicio de reprochabilidad al añadir que, además de ser personal, se motiva siempre que subsiste una exigencia de comportarse de manera diferente, por lo que requiere en corolario: a) la existencia de presupuestos de imputabilidad (una capacidad bifronte, que parte del conocimiento del injusto y arriba a concebir la alternativa de actuación diferente); b) conciencia de antijuridicidad (frente al acto imputado, se es consciente de que constituye un injusto); y c) la exigibilidad de actuar de forma diferente (posibilidad de autodeterminación conforme al ordenamiento penal) — esto a partir de Maurach y Kaufmann- (Schünemann, 1991, pp. 54, 56) ${ }^{21}$.

Es entonces que la culpabilidad se constituye, ya desde una perspectiva pragmática, en el reflejo de una acción retributiva por parte del Estado, por lo cual Schünemann la llama «retribución de la culpabilidad», ello como consecuencia de que la función de la pena se enfoca en retribuir la culpabilidad derivada de la comisión del injusto, la que paralelamente debe ser proporcional en el grado de culpabilidad del autor (Hormazábal, 2005; Schünemann, 1991b, p. 149). Así las cosas, Gimbernat Ordeig (1999) señala que «la antijuricidad es el ámbito del querery la culpabilidad el del poder» (p. 224) 22 , por lo que el castigo corresponde directamente a la posibilidad o imposibilidad de llevarlo a cabo. Ello deviene de la proyección político-criminal derivada de un delito, siendo un ejemplo clásico aquel generado por una fuerte presión psíquica en donde, al desear que sea justificado, se arraiga en la antijuridicidad; mientras que en casos como el de los delitos que carecen de dicha proyección políticocriminal, deben surtir su posibilidad exculpante a través del estudio de la culpabilidad.

Finalmente, la teoría preventiva de Roxín, una de las tesis más aceptadas, vislumbra el sentido de la culpabilidad (o, más bien, de los fines de este elemento) a través de la atribuibilidad originaria de las reglas de necesidad preventiva, bien sea esta general — valga decir,

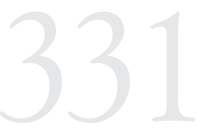

LA EXCULPACIÓN COMO CRITERIO

PUNITIVO FRENTE A DELITOS CONEXOS

A LA REBELIÓN

EN CONTEXTOS

DE CONFLICTO

ARMADO INTERNO:

UNA RELECTURA

DEL QUEHACER DEL

DERECHO PENAL

EN PROCESOS DE

PACIFICACIÓN

EXCULPATION

AS A PUNITIVE

CRITERIA AGAINST

CRIMES RELATED

TO REBELLION

IN CONTEXTS OF

INTERNAL ARMED

CONFLICT: A

REREADING OF

THE CRIMINAL

LAW WORK IN

PACIFICATION

PROCESSES

21 En este sentido, Rettig Espinoza (2009), analizando a Roxín (2006, pp. 822-823), concluye que la "culpabilidad, entendida como capacidad para comprender el injusto de su actuar y de actuar conforme a esa comprensión (imputabilidad)», genera la «posibilidad de conocimiento de la antijuridicidad y la normalidad de la situación en la que se actúa», perfeccionándose la «exigibilidad de otra conducta conforme a derecho» (p. 198).

22 Ver también Silva (1992, p. 413). 
cuando la sanción penal concurra como mecanismo necesario de reafirmación o confirmación social de los valores jurídicos presentados en el ordenamiento legal ${ }^{23}$ - y cuando unísonamente también posea una necesidad especial ${ }^{24}$ —referente al menester de la pena para la resocialización del delincuente- - De tal forma, es requisito que la imputación de culpabilidad primero restablezca la confianza general en la norma y que, seguidamente, sea completamente necesaria para la regeneración personal del individuo sancionado.

No obstante lo anterior, es menester hacer referencia a importantes críticas a la tesis prevencionista, toda vez que las necesidades preventivogenerales terminan instrumentalizando a las personas, siempre que se consolida un objetivo social devenido de una interpretación sesgada de las necesidades de las mayorías a través de una perspectiva judicial, desconociendo con ello la dignidad humana de cada individuo y su libre determinación ${ }^{25}$. Aunado a lo anterior, esta crítica se concadena con dos más de gran calado, la primera referente al estudio de «poder actuar de otra manera», lo cual es imposible de demostrar si consideramos detenidamente la imposibilidad de concretar la libre autodeterminación del ser humano (Schünemann, 1991b, p. 149; Velásquez, 1993, pp. 291-292). En segunda medida, si precisamos que la «responsabilidad de la persona se genera por su propio carácter»,

23 Dentro de esta, es menester distinguir dos acepciones diferenciadas: la primera, referente a una prevención general negativa, caracterizada por concebir a la pena como un mecanismo de intimidación para motivar a los ciudadanos a no lesionar bienes jurídicos penalmente protegidos (en la norma penal, mediante la conminación sancionatoria — formulada originalmente por Feuerbach - o la ejecución de la pena —desarrollada por el filósofo inglés Bentham, quien señaló el efecto disuasorio de la pena en su ejecución-); y la segunda, determinada como prevención general positiva, la cual desecha la intimidación de la amenaza penal como medio para motivar a los ciudadanos a no lesionar bienes jurídicos, por lo que tan solo es necesaria la pena justa y garantista capaz de confirmar los valores éticos del derecho (García, 2006, pp. 4-5).

24 Aun cuando desde la «teoría unificadora», la cual tiene importante aceptación doctrinal, combina «las concepciones [de] retribución, la prevención especial y prevención general como un todo que persiguen el mismo fin simultáneamente», aunque «manteniendo el elemento retributivo como la función dominante de la pena por la necesidad de expiación de culpa en el autor, considerándose los fines preventivos como secundarios o, inclusive, aleatorios en el mantenimiento del ordenamiento social» (Gómez Horta, 2016, p. 164).

$25 \mathrm{Si}$ bien con la tesis «prevencionista» se trata de omitir aquellos fines meramente retributivos en sede de culpabilidad, Morselli $(1995$, pp. $265,269,273)$ plantea que el fin retributivo por sí mismo se convierte en un mecanismo instrumentalizador para satisfacer las necesidades socioemotivas de la punición, las cuales son «irracionales y no respetuosas de la dignidad humana: el hombre no puede ser instrumentalizado para satisfacer semejantes deterioradas exigencias». En este sentido, el catedrático de la Universidad de Perugia concluye que la prevención no es el fin, sino es el efecto inducido de la función retributiva de la pena en cuanto esta satisface «las necesidades emotivas de la pena; una satisfacción que no es fin en sí mismo, si bien dirigida al absolvimiento de un mecanismo más profundo de defensa del Yo del individuo y de la sociedad, y más exactamente a la exigencia de neutralizar, o sea de remover los efectos de la turbación del equilibrio intra-psíquico colectivo, o sea de la alarma social, ocasionado por el hecho criminal en la conciencia colectiva». Con todo, es categórico en señalar que la eficacia integradora del sistema punitivo depende siempre de que se adquiera la «función retributiva y no lo será si sólo se ve en ella un instrumento político-criminal». Finalmente, es importante reconocer cómo Hegel encarnó la base filosófica de ambas críticas, al señalar, primero, que «la prevención general por medio de la amenaza (prevención general negativa) considera al individuo a nivel del can amenazado por el bastón", al tiempo que precisó (en defensa del análisis de la libertad, visto con mayor énfasis en el capítulo V.c); "sólo la pena impuesta al individuo por razón de su culpabilidad le honra como ser racional y libre. La pena que responde exclusivamente a razones de prevención le instrumentaliza». Para todo, ver Künsemüller (2001, pp. 150, 161). 
nos hallamos ante una contradicción si relatamos condiciones socioeconómicas, políticas y culturales diversas para cada persona, donde la dotación de culpabilidad no solo exige una diferenciación, sino que su aplicación homogénea implica la comisión de un acto de injusticia.

Es en este orden de ideas en el que autores como Hernán Hormazábal Malarée y Jesús Silva Sánchez precisan necesaria la adecuación del concepto y contenido de la culpabilidad, toda vez que la actual comprensión se cimenta en una perspectiva abstracta de «supuesta racionalidad homogénea», la cual solo oscurece la palpable «premisa de la desigualdad social», por lo que una respuesta eminentemente retributiva no puede generarse «sin la debida acción positiva de redistribución de los bienes sociales» (Hormazábal, 2005) que afecten el ámbito penal. Es entonces que Silva (1992) precisa que «el grado concreto de exigibilidad resultará de la conflictiva puesta en relación, por un lado, de las necesidades preventivas [...] y [...] de los argumentos utilitaristas de intervención mínima, criterios humanitarios, garantísticos, en suma, que apoyarían su reducción», a lo que se suma Hormazábal (2005) diciendo que «la responsabilidad no es sólo responsabilidad del autor por el injusto, sino también una responsabilidad social».

Siguiendo lo mencionado, nos enfrentamos a un estadio doctrinario penal, teñido de garantismo en sus elementos, que en su delineamiento antijurídico y culpable ha constituido figuras que rozan en sus particulares características y actualmente revisten imperiosa importancia: se trata de los estados de necesidad justificante y exculpante, el primero correspondiente a la antijuridicidad y el siguiente a la culpabilidad ${ }^{26}$, espacio en el que centraremos nuestra discusión.

Así las cosas, es necesario partir diciendo que las causales de justificación emanadas del estadio de antijuridicidad no son instrumentos penales homogéneos, pues tienen una funcionalidad diferencial conforme al peso —o entidad — de los bienes jurídicos tutelados y la puesta en peligro o riesgo de los mismos, de lo que resultará la producción de un EN justificante o bien el ejercicio de legítima defensa (Cerezo, 2000,

26 Es necesario considerar la existencia de diversas teorías frente a la ubicación del EN en la teoría del delito (Uribe, 2012, pp. 6-18; Luzón, 2016, p. 406), pasando desde las tesis de unificación, en las que el EN se encuentra solo como instrumento en la antijuridicidad (con Gimbernat a la cabeza [1990, pp. 218-230], seguido por Mantovani, Marinucci y Dolcini, Palazzo, Carbonell Mateu, y Muñoz Conde y García Arán), o bien solo en la culpabilidad (bajo la batuta de Goldschmidt [2010, p. 378], seguido por Mayer y Frank), hasta llegar a las tesis diferenciadoras —ya sea desde una visión ortodoxa en la que el EN se ubica como causa de justificación y exculpación (teoría mayoritaria, seguida por Bernal del Castillo, Fiandaca y Musco, Mezger, Welzel, Wessels, Stratenwerth, pero principalmente por Jescheck y Wigend [2002, pp. 377-394, 515-526], Roxín [1997, pp. 686-690], Mir Puig [1983, pp. 501-520] y Zaffaroni [2017, pp. 85-86; 2012, pp. 87-88], quien las une a las «técnicas de neutralización») - y las visiones heterodoxas, en donde el EN se presenta en el ámbito de la libre valoración de la prueba en el caso justificante (Kaufmann, 1997, pp. 407-419), o bien como una causa excluyente de la responsabilidad por el hecho (Maurach \& Zipf, 1994, pp. 465-466; 568).

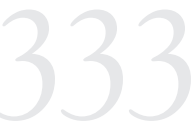

LA EXCULPACIÓN

COMO CRITERIO

PUNITIVO FRENTE A

DELITOS CONEXOS

A LA REBELIÓN

EN CONTEXTOS

DE CONFLICTO

ARMADO INTERNO:

UNA RELECTURA

DEL QUEHACER DEL

DERECHO PENAL

EN PROCESOS DE

PACIFICACIÓN

EXCULPATION

AS A PUNITIVE

CRITERIA AGAINST

CRIMES RELATED

TO REBELLION

IN CONTEXTS OF

INTERNAL ARMED

CONFLICT: A

REREADING OF

THE CRIMINAL

LAW WORK IN

PACIFICATION

PROCESSES 
p. 270). Con todo, el estado de necesidad justificante se sustenta en la existencia de causales de justificación que permiten, como ya se ha dicho, hacer coincidir a un hecho típico como lícito o, en otras palabras, ausente de antijuridicidad, lo que ha valido la reseña dogmática frente a que la teoría de la antijuridicidad se resuelve en una teoría de las causas de justificación (Künsemüller, 2001, pp. 73, 185; Cury, 1994; Bustos, 2005, pp. 62-64).

De esa manera, la doctrina reciente ha podido identificar dos perspectivas del estado de necesidad justificante: a) aquella originada de un estado agresivo, centrando directamente a la persona que comete el delito al ser afectada por circunstancias contextuales que la llevan a consolidarse en un estado de necesidad insuperable para sí o para terceros, y siendo su actuación un acto dañoso frente a una persona inocente; valga decir, que no ha sido responsable de dichas circunstancias contextuales. Esta institución tiene una acogida histórica en los ordenamientos jurídicos a partir de su consagración en el artículo 134 del Código de Hammurabi, el cual precisaba: «si alguien es hecho prisionero y, no habiendo en su casa de qué vivir su mujer entra en casa ajena, esta mujer es inocente» (Benítez, 2005, p. 27). De tal forma, actuaciones derivadas del hurto famélico o los derechos del propietario en caso de incendio del predio del vecino han generado que este constructo dogmático tomase fuerza como institución eximente de antijuridicidad (Wilenmann, 2014, pp. 216, 219).

Por otra parte, y a fin no estancar al estado de necesidad justificante en generalidades ${ }^{27}$, b) la segunda cara de esta institución del tipo penal se vislumbra en aquellas situaciones en las que se parte no de la persona poseedora de dicho «estado» (como en el instituto agresivo), sino de un tercero agresor que, sin existir una imputación cierta (es decir, generadora de peligro) y, por lo tanto, no completamente delictual (aunque podría serlo), genera con su accionar una prerrogativa de auxilio necesario para la persona afectada, estado al que se le conocerá como de «necesidad defensiva ${ }^{28}$.

27 Frente a este particular, Wilenmannn (2014) —estudiando a Lenckner — precisa que la regulación del estado de necesidad desde una perspectiva genérica «no es otra cosa que un cheque en blanco cuyo llenado el legislador debe dejarle al juez», lo cual implica serias dificultades de coherencia jurisprudencial sin lineamientos claros legales, siendo necesaria a toda costa "una norma concreta legislativa que le permita resolver o que le simplifique esencialmente la resolución al juez, [dado que] simplemente no puede ser efectuada a través de una disposición general del estado de necesidad» (p. 216).

$28 \mathrm{El}$ profesor Armaza Galdós (2009) precisa ilustrativamente un ejemplo para estos casos de EN justificante defensivo: «cuando traslada un conductor su vehículo, arriesgando la vida de sus pasajeros, ¿podrá el copiloto conjurar tal peligro a través de lesiones de poca monta que permitan hacerse del timón justo antes de estrellarse la máquina?, ¿qué eximente beneficiará a tal copiloto?» (p. 319) No obstante lo anterior, este elemento del EN justificante posee grandes semejanzas a lo postulado antiguamente por Alexander Lôffler como «legítima defensa restringida». Para su explicación, describió el síndrome del oligofrénico, en donde un sujeto que «dolosa y sostenidamente alumbra nuestros ojos con la luz solar reflejada en un espejo, sin más, no puede ser gravemente lesionado por 
Figura $\mathrm{N}^{\circ}$ 2. Antijuridicidad vs. culpabilidad

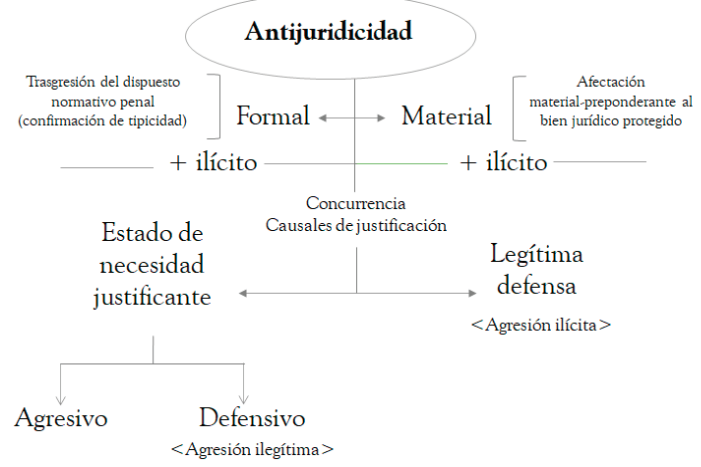

Fuente: elaboración propia.

Ahora bien, dentro de este estado de necesidad defensivo germina lo que conocemos como legítima defensa cuando la acción cruza la barrera delictual cierta $^{29}$, por lo que la conducta de respuesta devenida del actor a quien se le presenta un hecho dañoso corresponderá a una acción legitimada por el Estado (Armaza, 2009).

Cabe ciertamente precisar que existirán estados incompletos de necesidad e incluso frente a la legítima defensa, ello cuando los mismos incumplan con alguno de sus elementos; es decir, cuando en el EN agresivo no se configura una necesidad urgente que pudiese remediarse a través de otros medios; o, por el contrario, cuando existe ausencia de inocencia del tercero damnificado, siendo por tanto un contexto de legítima defensa. También, por parte del EN defensivo, cuando existe una reacción reflejo sin la existencia de un peligro relevante, por lo cual es un acto repelente no justificado, etc.; o simplemente cuando se desarrolla un resultado excesivo o plasmado hacia el agresor de una manera desproporcionada ${ }^{30}$, hecho que equivaldrá consecuencialmente a la falta de configuración de dichos institutos frente a la no consecución de antijuridicidad, derivando por tanto a disminuciones en grado casuístico de la pena.

nosotros y la defensa sólo se justificará si se emprendió subsidiaria y proporcionalmente» (Jakobs 1997, p. 472).

29 No obstante, cabe hacer mención de que lo postulado no se refiere a la naturaleza de los elementos psicológicos del análisis justificante, pues, como bien afirma Vera (2019, pp. 262, 264, 268), la "legítima defensa es una causa de justificación que pertenece al análisis del injusto», razón por la cual no requiere un análisis «ponderativo de proporcionalidad entre los bienes jurídicos en juego», aun cuando la práctica de esta «necesidad racional» legalmente admitida deba encontrarse en el marco del medio menos lesivo para su alcance (Roxín [1997, p. 668] la llama «el medio más benigno posible») a través de una racionalidad flexible —entiéndase, amplia - de la defensa empleada, por cuanto, al ser estricta, nos inmiscuiríamos en la proporcionalidad entre males, estructura más proclive al estado de necesidad.

30 Armaza Galdos (2014) «distingue entre el exceso extensivo y el intensivo. El primero existe cuando el agente se encuentra en una situación de necesidad imaginaria y, para "salvarse", perjudica un interés ajeno; el segundo, si se utiliza un medio más lesivo del que correspondía en el caso concreto» (p. 41).

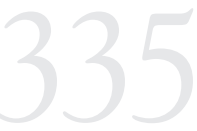

LA EXCULPACIÓN

COMO CRITERIO

PUNITIVO FRENTE A

DELITOS CONEXOS

A LA REBELIÓN

EN CONTEXTOS

DE CONFLICTO

ARMADO INTERNO:

UNA RELECTURA

DEL QUEHACER DEL

DERECHO PENAL

EN PROCESOS DE

PACIFICACIÓN

\section{EXCULPATION}

AS A PUNITIVE

CRITERIA AGAINST

CRIMES RELATED

TO REBELLION

IN CONTEXTS OF

INTERNAL ARMED

CONFLICT: A

REREADING OF

THE CRIMINAL

LAW WORK IN

PACIFICATION

PROCESSES 
Así las cosas, tanto los estados de necesidad justificantes agresivo y defensivo como la legítima defensa serán distinguibles en su estructura, valoración, fundamento y presupuestos de aplicación, los cuales definirán la situación de necesidad desarrollada en una circunstancia determinada, siempre dentro del espectro de la antijuridicidad.

Figura $N^{\circ} 3$. EN agresivo vs. EN defensivo

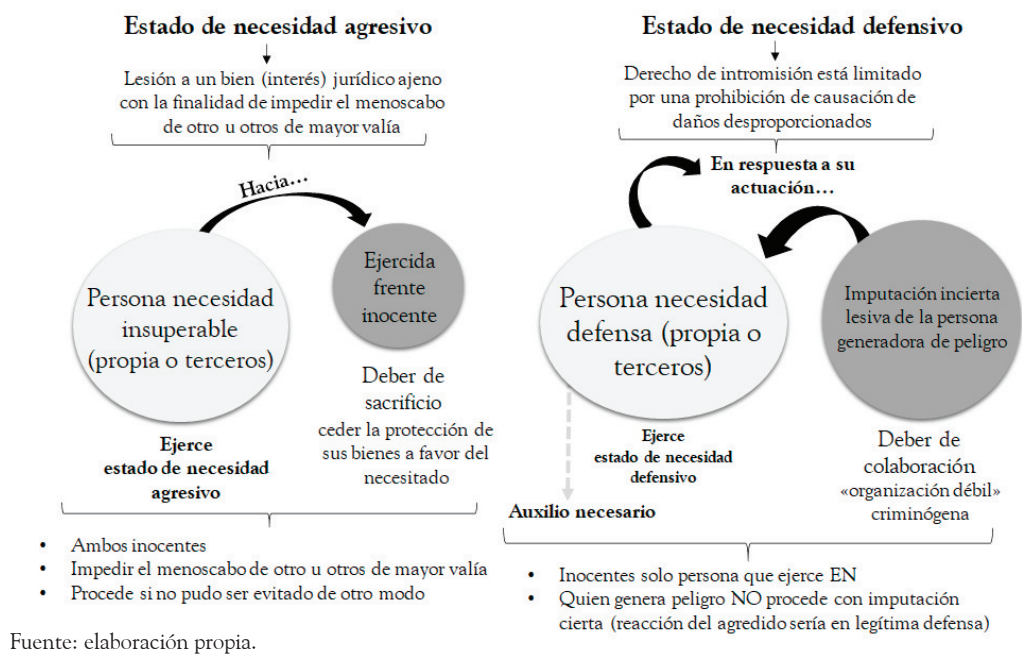

En coherencia con lo anteriormente precisado, veremos lógica la existencia de un grado de imputación diferenciado entre los EN defensivo y agresivo, así como en la legítima defensa, pues de estos se desprenderá el tratamiento sancionatorio hacia el sujeto agresor (EN defensivo y legítima defensa) y también la proyección de los deberes punitivos incumplidos en la estructura jurídica penal.

Figura N 4. Grado de imputación vs. estados de necesidad y legítima defensa

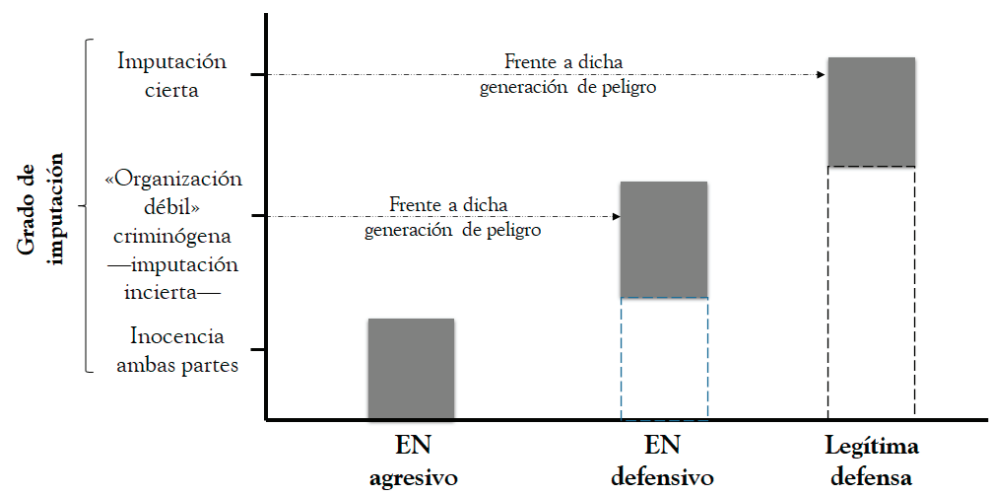

Fuente: elaboración propia. 
Consecuentemente, es necesario considerar que el desarrollo de la teoría del estado de necesidad posee en su esencia la exigencia de una contrapartida fáctica; es decir, una actitud de parte del sujeto generador de la ofensa — en el EN defensivo y legítima defensa- y del sujeto receptor del acto dañoso — en el EN agresivo—-, estando ambas reacciones fundamentadas en los deberes de ayuda y tolerancia derivados de la solidaridad (Wilenmann, 2014, p. 216), concepto que —a través de la dogmática penal alemana- es la base teórica del principio de justificación del estado de necesidad ${ }^{31}$.

Es así como, en reflejo del grado de imputación, se generará una suerte de escala frente al deber de solidaridad, siendo necesaria para el caso del EN agresivo la exigencia de un deber de sacrificio por parte del actor «agredido», en consecuencia de la necesidad insuperable del sujeto agresor (Piña, 2019, pp. 255, 257-258, 266). Mientras tanto, en el caso del EN defensivo y la legítima defensa, se exige un deber de colaboración ante la reacción del sujeto agresor como consecuencia - en el caso del EN defensivo- de un acto cuyo contenido posee una punibilidad incierta o en trasformación, a la par que en la legítima defensa se exige además un deber de tolerancia justificado en el hecho típico del finalmente agredido o repelido (Wilenmann, 2016, pp. 36-38).

Figura $N^{\circ}$ 5. Deber de solidaridad vs. estados de necesidad y legítima defensa

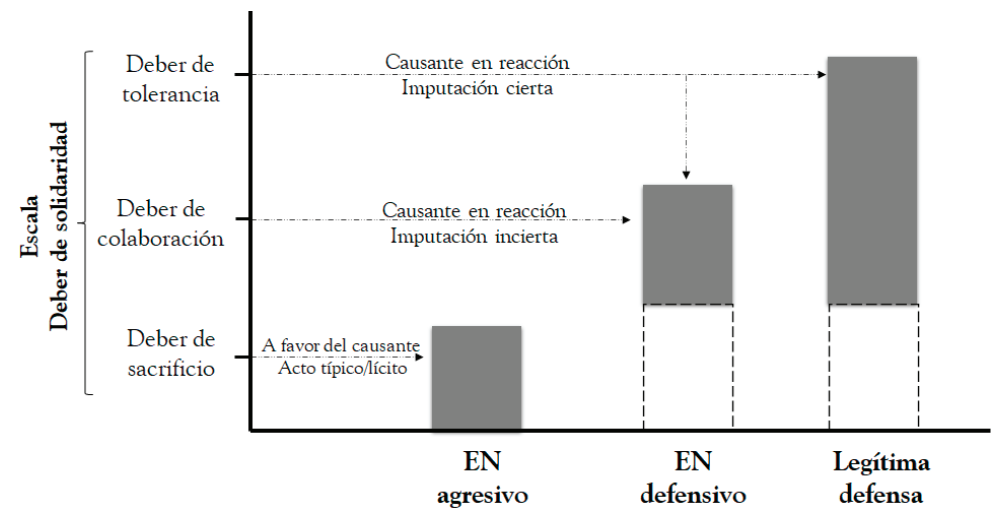

Fuente: elaboración propia.

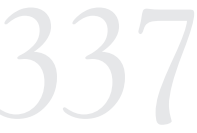

LA EXCULPACIÓN COMO CRITERIO

PUNITIVO FRENTE A

DELITOS CONEXOS

A LA REBELIÓN

EN CONTEXTOS

DE CONFLICTO

ARMADO INTERNO:

UNA RELECTURA

DEL QUEHACER DEL

DERECHO PENAL

EN PROCESOS DE

PACIFICACIÓN

EXCULPATION

AS A PUNITIVE

CRITERIA AGAINST

CRIMES RELATED

TO REBELLION

IN CONTEXTS OF

INTERNAL ARMED

CONFLICT: A

REREADING OF

THE CRIMINAL

LAW WORK IN

PACIFICATION

PROCESSES

31 Es necesario aclarar en igual medida que la construcción filosófica de solidaridad para algunos autores de la corriente alemana (Bayertz, Kymlicka) y latinoamericanos (Wilenmann) señala la conexidad inmanente con el utilitarismo benthamiano y stuartmilliano, ello siempre que esta corriente parta de la completa igualdad de valor de mis intereses y de los intereses de todo otro sujeto, lo que se encuentra en la base del utilitarismo como teoría de la justicia. No menos cierto será entonces considerar que en esta igualdad existe como mínimo un remanente de solidaridad ante la construcción de interés ajena. Todo ello debemos considerarlo para concluir reseñando que bajo la «solidaridad» existen construcciones también «utilitarias», por lo cual es un fundamento no solo coherente, sino complementario del deber de todo ciudadano ante contextos de estados de necesidad (Wilenmann, 2014, p. 234). 
En tal sentido, la dogmática penal se percató de la existencia de un vacío-conflicto cuando, al concebir que los pilares más elementales del EN justificante parten por lo general de la noción «del entendimiento de la no antijuridicidad de un daño cuando este ha evitado la comisión de un mal mayor» (Benítez, 2005, p. 28), dándose por hecho la existencia de una escala de valores que permitía realizar una medición de males, uno destinado a ser evitado (que finalmente no se realiza) y otro que se causa (mal efectivamente generado). En tal medida, si el EN justificante - genérico - se desprende de establecer la prevalencia ${ }^{32}$ del mal evitado —es decir, aquel que soporta un interés jurídico mayor que el mal finalmente causado (hecho que permite la justificación del acto «causado» a pesar de su tipicidad, pues, como recordamos, al incoar una causal de justificación, dicho acto es lícito)—, el cuestionamiento devenido se centró en la posibilidad de que algunos males existan en ciertos acontecimientos que, paralelamente, posean un equivalente mal, o incluso la concurrencia de un «mal causado» con una relativa mayor preponderancia jurídica sobre el evitado a través del apoderado del estado de necesidad ${ }^{33}$; es decir, que su acto generado por un estado de necesidad es relativamente menor —en importancia jurídica- que el del actor ofendido (agresivo) o causante (defensivo).

De tal modo, se originaria una distinción concreta, mediante escala de valores, entre el conflicto de deberes justificante (en su conjunto) y el exculpante — valga decir, derivado de la ponderación de males- en donde el primero ocurrirá si se sacrifica el deber causado cuando este posee menor valor $y$, por ende, es justificatorio; mientras que el segundo entrará a analizar la existencia de exculpación cuando ambos valores sean equivalentes, o limitadamente mayor el mal causado.

Dicho esto, nos daremos un espacio para ahondar en esta problemática. A continuación, nos sumergiremos en la observación de los panoramas del conflicto armado a fin de continuar posteriormente con la resolución de los actos que se observarán a través de la herramienta exculpatoria.

32 Entenderemos el concepto de «prevalencia» o «preponderancia» como el grado con que un sistema jurídico penal, tras la ponderación de derechos en una situación de conflicto determinado, concibe uno de ellos como más importante en su salvaguarda político-criminal. En este sentido, Roxín (2008) señala que, tratándose del EN justificante, «el autor ayuda a que se imponga un interés claramente preponderante, siendo valorada su intervención como socialmente provechosa y legal» (p. 639). Del mismo modo, Mir Puig (1998), refiriéndose a los tipos penales y su origen en cuanto puesta en peligro de bienes jurídico-penales, menciona que son exactamente estos «peligros» especialmente graves los que se «desea evitar si no concurre un interés prevalente que los justifique: el carácter penal de la antijuridicidad parte, pues, de un desvalor de resultado» (p. 131). Al respecto, ver Gomes (2015, pp. 372-387).

33 Dicha «relativa mayor preponderancia» no debe entenderse como una superación absoluta, pues no estaríamos en un plano de estado de necesidad, sino evidentemente en el de una atenuación sancionatoria. Para mayor claridad, ver figura 7. 


\section{III.1. Resolviendo algunos dilemas}

Ahora bien, no podemos dar estudio al acápite exculpatorio sin antes someter a análisis las posibilidades existentes de encontrar respuesta a nuestra investigación a través del estadio de la antijuridicidad; valga decir, legítima defensa y los estados de necesidad justificantes agresivo y defensivo.

Así las cosas, empezaremos descartando el remedio derivado de la legítima defensa para aquellos tipos conexos dentro de un conflicto armado, y lo motivaremos en el sentido de que su ejecución no puede poseer una justificación por parte del Estado mediante la legitimación del hecho delictivo como una defensa legítima. En este entendido, la defensa propia de los derechos debe encontrarse cubierta de una agresión ilegítima ${ }^{34}$; es decir, que ha usado medios no cubiertos por la ley. Es entonces que no podemos usar la herramienta de legítima defensa como justificante de tipos cuya motivación, primero, no proviene de una defensa ante una acción ilegítima, pues no estamos hablando de la rebelión en sí misma, sino de los conexos a esta; y, segundo, porque las características de los delitos constituyen un debatible medio racional para repeler la agresión — valga recordar- legítima por parte del Estado.

Con esto dicho, nos resta la observación de las dos vertientes del EN justificante. En primera medida, a partir del EN agresivo se desprende un interesante acercamiento de una defensa derivada de la antijuridicidad frente a los delitos conexos del conflicto armado, en tanto esta institución exige un deber de sacrificio por parte de la sociedad en general. No obstante, a pesar del papel de víctima de la sociedad frente a las vulneraciones generadas por el conflicto —en este caso, del bien jurídico tutelado de seguridad ciudadana, la salud pública, etc.—, estos delitos son solo el resultado de impedir el menoscabo de un interés de mayor valía o entidad — desde la perspectiva insurgente, la «paz» o la «justicia»—. Por su parte, desde la óptica del EN defensivo, también se viabiliza su aplicación cuando se exige al sujeto agresor —en este caso, el Estado - un deber de colaboración, toda vez que dicha actuación, si bien no es ilegal (pues correspondería al uso de legítima defensa), sî puede abarcar imputaciones lesivas que tendrían connotaciones al borde de la ilegitimidad. Ello, sin duda, no solo justifica el acto de rebelión (desde la perspectiva del grupo armado y sus integrantes), sino también centra a la acción estatal como «ilegítima» (como respuesta a la rebelión y sus delitos conexos), lo que se convierte en la motivación del ejercicio de los tipos penales y, con esto, en su configuración justificante.

Una vez dicho esto, debemos mencionar las complicaciones que se presentan en ambos escenarios, básicamente unidas en su estudio de

34 Bien lo precisa el § 32.2 del Código Penal Alemán al precisar que «Legítima defensa es la defensa que es necesaria para conjurar una agresión actual antijurídica para sí mismo o para otro» (1999, p. 11).

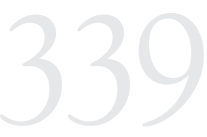

LA EXCULPACIÓN

COMO CRITERIO

PUNITIVO FRENTE A

DELITOS CONEXOS

A LA REBELIÓN

EN CONTEXTOS

DE CONFLICTO

ARMADO INTERNO:

UNA RELECTURA

DEL QUEHACER DEL

DERECHO PENAL

EN PROCESOS DE

PACIFICACIÓN

EXCULPATION

AS A PUNITIVE

CRITERIA AGAINST

CRIMES RELATED

TO REBELLION

IN CONTEXTS OF

INTERNAL ARMED

CONFLICT: A

REREADING OF

THE CRIMINAL

LAW WORK IN

PACIFICATION

PROCESSES 
exoneración antijurídica, ya que la ponderación de valores de los males causados en los estados de necesidad posee — desde la perspectiva de quien escribe - una débil consolidación de excepción a la imperativa exigencia de cumplimiento del ordenamiento penal. Esto porque: a) no solo no se consagra precedente a la actuación un criterio permisivo que dote al sujeto activo de conocimiento del eximente antijurídico del tipo $^{35}$, sino que también b) se vislumbra un difícil cálculo valórico que - posea un resultado unánime y- permita justificar los delitos conexos que cometieron los actores armados, tanto en su variante defensiva (siempre que la ilegitimidad del acto devenido del Estado - y a partir de la cual se motiva la defensa del actor armado - sea una percepción jurídica subjetiva de una colectividad, en este caso del grupo rebelde y no de la generalidad) ${ }^{36}$ como también en su variante agresiva, aunque en menor proporción (por cuanto, aun aceptando el carácter insuperable de la necesidad de rebelarse del actor armado, ello requiere la ausencia de otros medios que hayan podido evitar el hecho dañoso, lo cual a la vez es indeterminado y no posee valóricamente una preponderancia sustancial aceptada por la sociedad y el sistema judicial) ${ }^{37}$.

En estas condiciones, la aplicabilidad de cualquiera de los estados de necesidad derivados de la antijuridicidad presenta grandes dificultades para asumir un eximente normativo de responsabilidad, siendo más conducente para este camino el hallar dicha justificación en el ámbito de la falta de reprochabilidad asentada en sede de culpabilidad, en la que se puede reconocer la existencia del injusto cometido y, paralelamente, la no conducencia de una sanción por parte del Estado. El sentido contrario sería reconocer abiertamente que el ejercicio de la rebelión daría permisión jurídico-penal, valga decir, lícita ante la falta de antijuridicidad, para la comisión de delitos —más entendibles en el consciente colectivo y en la racionalidad jurídica- como porte ilegal de armas, pero también de otros más reprochables y difíciles de asimilar como extorsión, financiación u ocultamiento de actividades

35 Esto en el sentido de que es difícil considerar que un grupo alzado en armas (los o las integrantes de este) desconozca la ilicitud de su acción insubordinada, o bien considere la existencia de una justificación frente a la antijuridicidad (no configurando, por tanto, un injusto), siempre que esto esté en contra de los mismos fines insurgentes de trasformación del Estado. Así, no pueden someterse en su consciente a las reglas de un Estado que piensan, en teoría, abolir o trasformar profundamente; ni, peor aún, creer que existen eximentes a su actuación. Con ello, por último, queremos concluir la comprensión del injusto de los actores rebeldes, lo que los localiza en sede de culpabilidad.

36 Asimismo, debemos recordar que en la dogmática penal alemana, el EN defensivo cobra regulación no solo a partir del $§ 34$ del Código Penal, sino también del $§ 228$ del Código Civil, el cual exige para su configuración «que el deterioro o la destrucción sean necesarios para apartar el peligro y el daño no sea desproporcionado frente al peligro» (Pawlik, 2013, p. 14). En tal medida, la comisión de delitos conexos derivados de la rebelión tiene un alto margen de fracaso ante el análisis tanto de su necesidad como de su proporcionalidad frente a la persecución estatal y al sostenimiento de la rebeldía.

37 En este mismo orden de ideas, Michael Pawlik (2013) hace referencia a que «en los supuestos del estado de necesidad agresivo el derecho de intromisión está fundamentado en la preponderancia sustancial del interés salvaguardado frente al interés lesionado» (pp. 14-15), lo cual, como ya se ha establecido, no posee una respuesta unánime sino, por el contrario, matices que permiten vislumbrar respuestas diferenciales de acuerdo al actor en confrontación. 
ilícitas, e incluso narcotráfico. La respuesta en sede de culpabilidad la detallaremos en el siguiente acápite.

\section{JUSTIFICACIÓN DE LA APLICABILIDAD DEL ESTADO DE NECESIDAD EXCULPANTE EN CONTEXTOS DE CONFLICTO ARMADO Y SU IMPORTANCIA EN EL ANDAR CIENTÍFICO DEL DERECHO PENAL}

Tal y como precisamos en nuestra parte introductoria, el objetivo de la ciencia penal es recubrir garantísticamente todos los espacios posibles de vulneración de derechos, blindando la armonía perfecta entre el principio de seguridad jurídica y el de tutela judicial efectiva. Así, la cientificidad con la que se trata la dogmática penal parte de a) su adecuación empírica con los conflictos pragmáticos de lo social, frente a lo que consolida b) enunciados normativos libres de contradicción, resultando de c) su sistematización de teorías aplicables a estadios específicos de dicho conflicto, todo ello bajo d) fuertes correlatos de motivación que permitan la discusión dogmática y su crítica frente a su falsedad científica (Kindhäuser, 2009, pp. 955-958; Schurmann, 2019, pp. 556-557).

En esta medida, el tratamiento jurisdiccional de delitos de naturaleza política (eminentemente, el de rebelión y los conexos a este) en conflictos armados internos dentro de un escenario de pacificación o justicia transicional no solo no debe, sino que no puede ser observado $\multimap$ si se quiere, deconstruido- desde un panorama de política criminal errante, cimentada en los diálogos eminentemente políticos de la guerra; sino que, por el contrario, estos en primer orden deben obedecer a respuestas propias de la dogmática penal, cuyo método científico permita la resolución de controversias independientes del proyecto político - de interfaz - que tenga un gobierno de turno en un contexto en donde la beligerancia se encuentra en una quebrantable balanza. De la misma manera, dicha política-criminal posacuerdos debe ser guiada por su carácter reconciliador en miras a la obtención de los mayores fines del derecho como institución: la paz, la seguridad y la justicia (Squella, 2014, pp. 634-637), elementos que evidentemente no pueden ser alcanzados en un contexto de conflicto (ausencia de eficacia normativa e institucional).

De tal forma, debemos retrotraer lo anunciado anteriormente por Hormazábal Malarée (2005) al objetar que en la comisión de algunos tipos penales, «la responsabilidad no es sólo responsabilidad del autor por el injusto, sino también una responsabilidad social», por lo que, bajo la lupa de la reprochabilidad, se extiende también un componente fáctico-moral que tiene indiscutible valor al momento de impetrar una

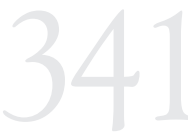

LA EXCULPACIÓN COMO CRITERIO PUNITIVO FRENTE A DELITOS CONEXOS A LA REBELIÓN EN CONTEXTOS DE CONFLICTO ARMADO INTERNO: UNA RELECTURA DEL QUEHACER DEL DERECHO PENAL EN PROCESOS DE PACIFICACIÓN

EXCULPATION AS A PUNITIVE CRITERIA AGAINST CRIMES RELATED TO REBELLION IN CONTEXTS OF INTERNAL ARMED CONFLICT: A REREADING OF THE CRIMINAL LAW WORK IN PACIFICATION PROCESSES 
sanción penal. Por ello, aun cuando el resultado típico y antijurídico se confirme, la culpabilidad debe poseer un análisis profundo sobre la correspondencia o no de una pena de acuerdo a los matices sociales que hayan influido al actor a cometer dicho delito ${ }^{38}$.

De este modo, y ya realizada una introducción necesaria hacia el sistema propositivo objeto de este estudio, hemos de retomar la deliberación del acápite II, siendo menester precisar que el EN exculpante se distinguirá del justificante, en principio, mediante la escala de valores a la que se someten el mal a evitar y el mal causado ${ }^{39}$, ello a través del nivel de preponderancia que estos posean ${ }^{40}$. Basta considerar para ello lo constituido por el $§ 34$ del Código Penal Alemán al establecer frente al EN justificante que «no actúa antijurídicamente si en la ponderación de los intereses en conflicto, en particular de los bienes jurídicos afectados, y de su grado del peligro amenazante, prevalecen esencialmente los intereses protegidos sobre los perjudicados». En el caso del EN exculpante (\$35), se pronuncia solo como una oportunidad genérica de inculpabilidad al encontrarse «un peligro actual para la vida, el cuerpo o la libertad no evitable de otra manera» ${ }^{41}$, a través del cual se "cometa un hecho antijurídico con el fin de evitar el peligro para él, para un pariente o para otra persona allegada»; advirtiéndose, no obstante, que «no rige en tanto que al autor se le pueda exigir tolerar el peligro, de acuerdo con las circunstancias particulares, porque él mismo ha causado el peligro o porque él estaba en una especial relación jurídica» ${ }^{42}$.

A pesar de esta distinción encontrada continuamente en la dogmática penal, no es un tema inacabado en el empirismo ético, pues el mero hecho de la ponderación de valores de los bienes jurídicos puestos en riesgo en un escenario de estado de necesidad puede, en muchos casos,

38 Ello, por supuesto, no puede derivarnos a la prohibición de regreso propia del error de tipo, pero tampoco nos puede impedir recepcionar una perspectiva obtusa de la realidad cuando la misma influye fundamentalmente en la planeación y realización de un hecho delictivo.

39 En este sentido, Vives Antón y Cobos del Rosal (1999) precisan: «la dogmática manifiesta que es necesario realizar una ponderación de males en cuanto a la lesión que se produjo o que podría originar, teniendo en cuenta los efectos que podrían ocasionarse si se ataca un bien o interés en lugar del otro y/o viceversa» (p. 534).

40 Sin embargo, cabe advertir que el mismo Muñoz Conde (2017) no comparte la adquisición del EN exculpante de aquellos casos en los que la ponderación de valores jurídicos es la misma. Tal es el caso del auxilio necesario ocasionado, por ejemplo, al médico que debe proporcionar sangre a dos pacientes en riesgo vital, teniendo solo consigo la sangre necesaria para uno de ellos; o, también, el caso de dos náufragos (similar al caso de la tabla de Carneades) que no disponen de salvavidas, y un tercero posee solo un salvavidas restante. En estos casos, Muñoz Conde sugiere que también debe generarse un estudio en sede de antijuridicidad y, por tanto, derivarse un estado de necesidad justificante.

41 Por esta razón, Figueiredo (2011) considera restringidos los bienes jurídicos ponderables para el EN exculpante (también llamado disculpante), en tanto son solo aquellos «individuales elementales: la vida, la integridad física y la libertad» (pp. 613-614).

42 De este modo, precisa Jesús Gómez López (2003) que la diferencia entre el EN justificante y aquel disculpante «radica en que la primera existe una colisión entre un bien de mayor valor y uno de menor valor, donde se sacrifica el de menor valor; mientras que en el estado de necesidad disculpante existe necesariamente una colisión de dos bienes jurídicos de igual valor, en donde el mal evitado no es mayor al mal ocasionado» (pp. 1165-1166). Ver también Gómez Huilca (2017, p. 46). 
llegar a graves inconsistencias e incoherencias pragmáticas ${ }^{43}$. En tal medida, no se puede considerar la intervención de las figuras de estado de necesidad como un simple cálculo matemático y, por ende, se requiere fronteras de mayor determinación para su aplicabilidad ${ }^{44}$. Una de estas se ha establecido a través de la dignidad humana determinada por Roxín, quien la considera un límite que inadmite toda ponderación valórica ${ }^{45}$. Esto en referencia a casos como las denominadas «torturas de salvación» (Muñoz, 2017), tesis que es defendida de manera contundente por Jeremy Waldron al mencionar que la evolución del derecho penal ha generado la existencia ciertos inadmisibles, verbigracia la esclavitud y la tortura, los cuales no pueden ser constituidos como un elemento cuantificable, medible o ponderable en una balanza de valores jurídicos ${ }^{46}$, pues estos sobresalen del pizarrón analítico y guardan protección superior.

Por su parte, algunos autores como Mir Puig consideran al estado de necesidad como herramientas jurídico penales peligrosistas, prefiriendo, por tanto, implementar para los casos difíciles de falta de antijuridicidad o culpabilidad el denominado «miedo insuperable» — tratado en el derecho anglosajón como duress ${ }^{47}$ - como eximente en sede de culpabilidad (Mir Puig, 2016; Muñoz, 2017; Suñez, 2013, p. 11), lo que implica asumir una solución razonable de exoneración del reproche estatal y despojarse de las ponderaciones valóricas ${ }^{48}$ que pueden tener respuestas incoherentes con el resto de instituciones garantistas

43 Valga sostener el ejemplo de la atención en salud de dos infantes: uno de condiciones económicas altas y con innumerables oportunidades académicas, y otro de estratificación baja y, por ello, sin ningún nivel académico. La ponderación de valores jurídicos podría arrojar el salvamento indiscutible del infante con mayores recursos académicos, generando en la determinación de la justicia un núcleo de razonabilidad clasista y discriminativo, lo cual deriva a una incoherencia teórica de las bases constitucionales con los resultados pragmáticos de las instituciones jurídico-penales.

44 Nuevamente nos referiremos a Muñoz Conde (2017), quien precisa de forma interesante: «la justicia es mucho más que una balanza».

45 Roxín indica para el caso específico de la ponderación de vidas que «cuando hay vidas humanas que entran en peligro en común con otras, pugna con el sentimiento moral utilizarlas como meras partidas contables en una cuenta global». Ver Gómez Huilca (2017, p. 39).

46 Para un estudio más profundo sobre el autor, interesante es observar el texto Torture and Positive Law: Jurisprudence for the White House, que refiere a los límites que deben existir por parte del Estado —en este caso, específicamente el Departamento de Justicia de los Estados Unidos- frente a circunstancias como infligir dolor durante el interrogatorio de sospechosos de terrorismo (Waldron, 2004; Muñoz, 2017).

47 Equivalente en el common law a la coacción o fuerza como una excusa (excuse) completa, en donde se requiere que dicho «miedo insuperable» se haya generado «bajo amenazas de muerte o daño corporal serio para sí o para un tercero (cercano), que el actor crea razonablemente que existe la amenaza o que ésta sea genuina [... y] que la amenaza sea presente e inminente» (Correa, 2016, p. 205). En este sentido, Guerra (2019, pp. 55-56, 68) sostiene que el miedo insuperable, diferente del estado de necesidad y la legítima defensa, recurre solo en aquellos peligros reales que han generado una situación de insuperabilidad, por lo cual no conlleva un trastorno del juicio de la realidad prefiriendo entonces llamarlo — junto con Labatut_ «impulso irresistible» (por tanto, afirma el autor, «el peligro imaginario en casos de miedo insuperable es parte del error de prohibición» (p. 76).

48 En el mismo sentido, es interesante mencionar la tesis de Gabriela Gómez Huilca (2017), quien precisa como regla que aparta la ponderación valórica la máxima de «inexigibilidad de una conducta», siempre que «a un individuo común no se le puede exigir un comportamiento diferente, si cualquiera en ese mismo lugar haría la misma conducta, ya que no tiene otra opción, siendo la única para salvaguardar su bien jurídico o el de un tercero» (pp. 63-64).

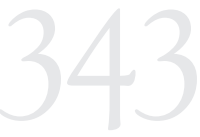

LA EXCULPACIÓN

COMO CRITERIO

PUNITIVO FRENTE A

DELITOS CONEXOS

A LA REBELIÓN

EN CONTEXTOS

DE CONFLICTO

ARMADO INTERNO:

UNA RELECTURA

DEL QUEHACER DEL

DERECHO PENAL

EN PROCESOS DE

PACIFICACIÓN

EXCULPATION

AS A PUNITIVE

CRITERIA AGAINST

CRIMES RELATED

TO REBELLION

IN CONTEXTS OF

INTERNAL ARMED

CONFLICT: A

REREADING OF

THE CRIMINAL

LAW WORK IN

PACIFICATION

PROCESSES 
del ordenamiento jurídico, sobre todo constitucional y del derecho internacional de los derechos humanos.

Así las cosas, la mera ponderación de valores como núcleo de diferenciación de los estados de necesidad no es suficiente para dotarlas de una fortaleza jurídico-penal que les brinde sostenibilidad en la teoría del delito. Es por ello que existen en la doctrina exigencias específicas que configuran cada institución en tanto criterios de análisis, tales como la gravedad, la lesión, el carácter recuperable y la afectación, generando una comparación valorativa de males colisionados bajo un criterio neutral (Quinteros, 2010, p. 40; Gómez Huilca, 2017, p. 37), esto sin querer decir que también se establezcan requisitos genéricos para ambas instituciones. En ese sentido, entre aquellos requisitos conjuntamente establecidos para los dos EN, justificante y exculpante, se encuentran a) la situación de necesidad para un bien jurídico; esto es, la existencia de colisión de bienes o intereses cuyo resultado genera forzosamente sacrificar uno de estos, provocando dicho conflicto un verdadero estado de necesidad (Vives \& Cobos, 1999, p. 522). En el mismo sentido, deben configurar b) una situación de peligro, la cual puede ser tanto inminente como un peligro futuro, siendo requisito para la existencia de este elemento la precisa intervención de la actividad que fundó el EN ${ }^{49}$.

Ahora bien, en cuanto los requisitos propios o específicos de cada EN, tratándose del justificante se hallan: a) el interés preponderante, b) la acción justificada o grado motivacional, y c) la ausencia de provocación; mientras que para el EN exculpante se presentan dos tipos de características: a) la teórica, concebida en la proporcionalidad de males, y b) las deducibles, que recaen en las que denominaremos b.i) déficit motivacional y b.ii) probabilidad de provocación.

Como podemos observar, la diferenciación de las dos figuras de los EN recae, además de en la ponderación valórica (interés preponderante para el EN justificante y proporcionalidad de males para el exculpante), en la gradualidad de dos características; a saber, el grado motivacional y de provocación.

De tal forma, en el EN justificante se requiere que la acción desarrollada a fin de resguardar el bien jurídicamente tutelado de mayor relevancia sea la más idónea para el logro del objetivo protectorio propuesto (Vives \& Cobos, 1999, p. 526), por lo que para esta institución se exige un nivel motivacional alto. En el EN exculpante, por su parte, el grado motivacional es más difuso, pues no corresponde su justificación como una respuesta legal, sino como parte de un eximente de reproche,

49 Gómez Huilca (2017) lo explica de forma clara, retomando a Mir Puig, al considerar que «para decidir si concurre la probabilidad inminente de peligro, "el juez debe retrotraerse al momento en que actuó el agente (ex ante)" y enjuiciar la situación según cómo se hubiera comportado un hombre medio con los conocimientos que cualquier sujeto podría tener» (p. 37). 
valga decir, de última ratio, en donde se pretende dotar de coherencia al ordenamiento penal a través del último instituto de la teoría del delito ${ }^{50}$. No obstante lo anterior, esto no quiere decir que no deba existir correspondencia entre la acción exculpada mediante el EN y el interés salvaguardado, sino que el grado de exigibilidad es menor al presentado en sede justificante.

Por otro lado, frente al grado de provocación, el EN justificante exige su ausencia, en el sentido no de una realidad fáctica ante la aparición de un EN autoprovocado (el cual solo puede reconocerse), sino como requisito para la consolidación del carácter «justificante» que este exige tener para constituir la ausencia de antijuridicidad ${ }^{51}$. Lo contrario implicaría admitir que el derecho penal, a pesar de no reconocer la facultad de un individuo para actuar contra legem, al tiempo le brinda garantías para provocar el contexto que exija a este sujeto actuar de dicha manera típica $^{52}$. Por su parte, en sede de culpabilidad, el EN exculpante, en tanto reconoce la acción como un injusto penal (no siendo reconocido ningún justificante legal), difiere su análisis de reproche a través del estudio de la situación de peligro y el grado de motivación, así como de la gravedad del resultado y el grado de recuperación de la afectación, todo ello abarcado en la recién mencionada proporcionalidad de males producto de la comparación valorativa de males colisionados, cuyo resultado puede restringir el impacto de reprochabilidad ya sea eximiéndolo o disminuyéndolo (Luzón, 2012, p. 265; Gómez Huilca, 2017, pp. 52-53; Guerra, 2019, p. 57; Vera, 2019, pp. 266, 268-269).

A pesar de lo comentado, es preciso decir que pese a los requisitos adicionales para la aplicabilidad del EN exculpante, estos se remiten a una posición subjetiva del resultado generado derivado de la decisión, incapacitada de ser lícita (justificada en sede antijurídica), pero imposibilitada para ser sancionada, a fin de brindar coherencia jurídica al ordenamiento penal y otorgar respuesta efectiva a una demanda social. En tal medida, Zárate Conde y González (2015) precisan:

50 En este sentido, surte gran importancia referirnos al denominado «espacio libre de derecho", por lo que, remitiéndonos a Lothar Philipps, observamos que este señala que «el espacio libre de derecho constituye el ámbito normativo de lo no prohibido para lo que, sin embargo, no es posible inferir una autorización o —equivalentemente- el ámbito de lo no permitido que no está, así mismo [sic], autorizado» (Kaufmann, 1999, p. 415). De tal forma, Carranza Piña (2011) considera que «el espacio libre de derecho aboga y significa que el orden jurídico renuncia a valorar la conducta respectiva. Es decir, se establece que si bien hay una conducta que es relevante para el derecho penal, su comportamiento y resultado, no le es exigible y por ende no puede ser punible» (p. 169).

51 En esa línea, el catedrático mexicano Javier Jiménez Martínez considera que una persona, al autoimponerse una situación de conflicto y peligro, presenta una conducta con carácter típico que no queda cubierta por una justificación legal. No obstante, el individuo sí genera una situación de necesidad, aun cuando no esté justificada (Gómez Huilca, 2017, p. 42).

52 Es necesario precisar que dentro del EN justificante se permite, de acuerdo a doctrinantes como Ansúa y Manzini (2004), que la provocación de peligro del propio EN haya sido generada por un tercero, siendo el accionar del actor imputado justificado siempre que este actúe sin la «asunción del riesgo voluntariamente afrontado» (p. 278).

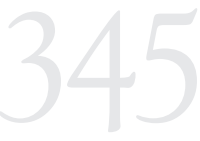

LA EXCULPACIÓN COMO CRITERIO

PUNITIVO FRENTE A

DELITOS CONEXOS

A LA REBELIÓN

EN CONTEXTOS

DE CONFLICTO

ARMADO INTERNO:

UNA RELECTURA

DEL QUEHACER DEL

DERECHO PENAL

EN PROCESOS DE

PACIFICACIÓN

EXCULPATION

AS A PUNITIVE

CRITERIA AGAINST

CRIMES RELATED

TO REBELLION

IN CONTEXTS OF

INTERNAL ARMED

CONFLICT: A

REREADING OF

THE CRIMINAL

LAW WORK IN

PACIFICATION

PROCESSES 
la inexcusabilidad del remedio [...] es la inevitabilidad del mal que constriñe al sujeto a la acción lesiva de los bienes ajenos. A diferencia de la fuerza mayor, en la que no se puede escoger, en el estado de necesidad se puede escoger, pero la alternativa que tiene el sujeto de reaccionar de otra manera queda reducida por la premura psicológica (p. 261).

Ahora bien, no es extraño considerar a la teoría del estado de necesidad desde sus dos prismas, el antijurídico (justificante) y el culpable (exculpante), como una construcción doctrinalmente conflictiva, siendo este escenario probablemente un acontecer insuperable pues el estado de necesidad es una institución que tiene un núcleo argumentativo problemático $^{53}$, por lo que es probable que una sensación de crisis le sea inmanente (Wilenmann, 2014, p. 216), de forma que el acuerdo -O alineación - sistemático de toda la doctrina frente a este instituto es un hecho casi imposible.

Así, pese a la complejidad de la ponderación valórica en los EN, estos poseen una gran utilidad para otorgar respuestas desde la teoría del delito a tipos penales aplicables en contextos de crisis, siempre que el hermetismo resolutivo de estas situaciones — desde una comprensión conservadora de la antijuridicidad y, sobre todo, la culpabilidad — pueda implicar que el ejercicio jurisdiccional penal sea un tropiezo hacia la resolución de conflictos sociales de gran envergadura (siendo, en tanto, la producción de sanciones su única respuesta como remedio ineficaz), verbigracia a lo acontecido frente a los delitos conexos a la rebelión, a los que — sostenemos — no deben serle abrogadas sanciones cuando se encuentra en curso un proceso de justicia transicional.

Por tanto, acogeremos primordialmente la perspectiva doctrinal en la que se distingue entre el EN justificante y el exculpante (tesis diferenciadora ortodoxa), y donde este último entiende el desmedro sobre un bien de igual (Armaza, 2009, p. 2; Uribe, 2012, pp. 3-4) o mayor jerarquía que el salvado (Wilenmann, 2014, pp. 215, 219, 221, 223); mientras que en el justificante, el bien perjudicado es siempre menos valioso (Castillo, 2016, pp. 341, 349; Armaza, 2009, p. 40; Guerra, 2020, pp. 8, 11), momento en el cual se hace imperante la escala de valores, pues al verse vulnerado de forma relevante el interés jurídico depositado en el mal causado, se generará consecuentemente no un EN exculpante, sino por el contrario una atenuación sancionatoria ${ }^{54}$.

53 Bien precisa Santiago Mir Puig, resumiendo el conflicto del EN, que dicha institución prevé un espacio de igualdad de legitimidad frente a las situaciones de los sujetos, por lo que se resuelve el conflicto en la importancia de los intereses en juego y, por ende, se genera una solución que se ata a la persona, el contexto y el tiempo en que se resuelve el dilema (Gómez Huilca, 2017, p. 48).

54 De esta manera, Cerezo Mir (1981), apoyándose en Antón Oneca, Calon-Camargo y Córdoba Roda, precisa que «cuando falta alguna de las circunstancias que sirven de base a las causas de justificación, reguladas en el artículo 8vo, se aprecia una atenuante (eximente incompleta) [...] En la legítima defensa, por ejemplo, se consideran esenciales los requisitos de la agresión ilegítima y de la necesidad de la defensa y como inesenciales — para la apreciación de la atenuante- que la defensa 
Figura $\mathrm{N}^{\circ} 6$. Nivel de preponderancia

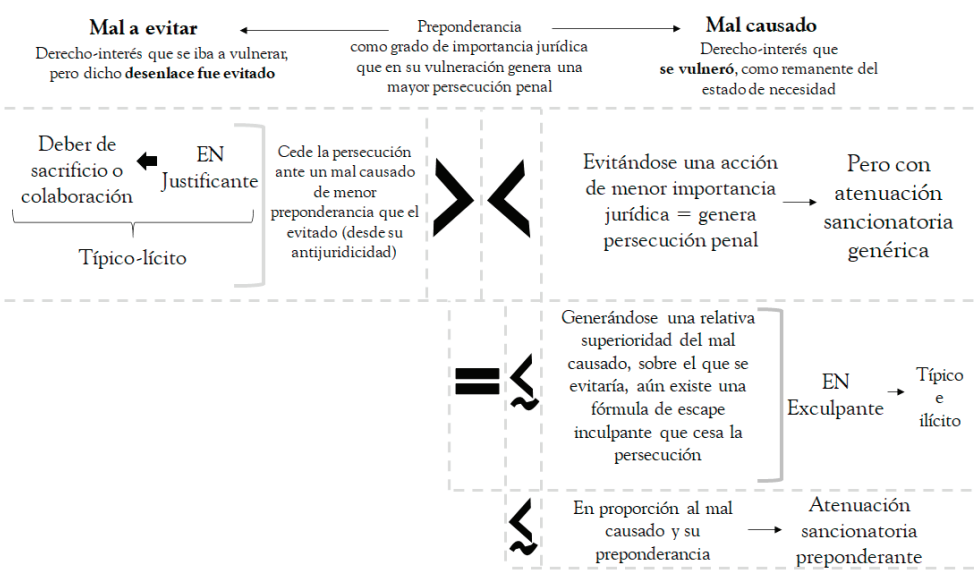

Fuente: elaboración propia.

$3<1$

LA EXCULPACIÓN

COMO CRITERIO

PUNITIVO FRENTE A

DELITOS CONEXOS

A LA REBELIÓN

EN CONTEXTOS

DE CONFLICTO

ARMADO INTERNO:

UNA RELECTURA

DEL QUEHACER DEL

DERECHO PENAL

EN PROCESOS DE

PACIFICACIÓN

EXCULPATION

AS A PUNITIVE

CRITERIA AGAINST

CRIMES RELATED

TO REBELLION

IN CONTEXTS OF

INTERNAL ARMED

CONFLICT: A

REREADING OF

THE CRIMINAL

LAW WORK IN

PACIFICATION

PROCESSES provocando así en el proceso punitivo una atenuación sancionatoria en la que el hecho es típico, antijurídico, culpable y, por lo mismo, un acto ilícito y delictual, pero con atenuación en su pena ${ }^{55}$.

Aún más interesante podemos considerar el que las referencias doctrinales postuladas nos hagan prever la existencia, dentro de la escala de preponderancia, de un «nivel medio de equivalencia» en el que el «mal causado» y el «mal evitado» coinciden debido a su homogénea o relativa equivalencia en su valor o importancia jurídica. La siguiente figura busca resumir los párrafos anteriores:

no vaya más allá de lo necesario para rechazar la agresión y la falta de provocación suficiente po parte del que se defiende» (p. 458).

55 Como observamos, esta problemática entre variables y criterios de distinción posee una gran relevancia, pero no se abordará en este trabajo pues excede su objetivo primario. 


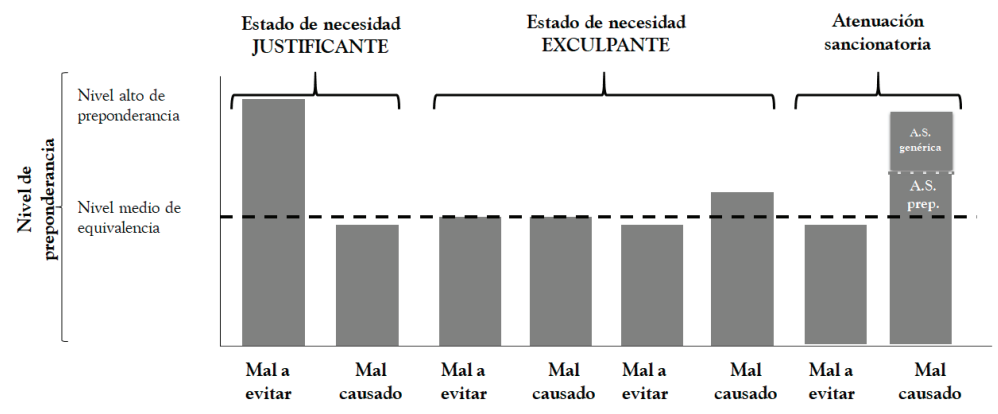

Fuente: elaboración propia.

Con todo lo observado, será momento de establecer — desde la teoría del delito y las herramientas exculpatorias - nuestra propuesta a la problemática de delitos conexos en escenarios de conflicto armado interno en los que se desarrollen procesos de pacificación.

\section{IV.1. Propuesta}

Hemos de añadir de primera mano que nos encontramos con la imposibilidad de considerar las acciones delictuales conexas al conflicto salvaguardadas dentro delENjustificante; valga decir, su estudio no puede pasar por la antijuridicidad o juridicidad del acto, pues evidentemente no podrá enmarcarse dentro de las causales justificatorias desprendidas del ordenamiento jurídico, siendo por tanto hechos indiscutiblemente típicos, ilícitos y antijurídicos.

Ahora bien, al quedar bajo el estudio de culpabilidad, requeriremos añadir una doble visión:

- La primera, sometida a los lineamientos de Roxín frente a la teoría de la necesidad preventiva, en la que exigiremos, bajo un escenario de proceso de paz, el cuestionamiento de existencia de prevención especial y general (Silva, 1992, p. 295), siendo su falta de necesidad el camino que brinda apertura a la omisión de culpabilidad.

- La segunda: una vez integrados en la institución de culpabilidad, desarrollaremos un análisis del deber de solidaridad y su misión en la «escala de valores de preponderancia», sometidos al carácter de los delitos conexos y la justificación de la rebelión en los Estados democráticos.

Definido lo anterior, comenzaremos diciendo que los conflictos armados de cualquier magnitud encuentran su punto de inflexión en los espacios 
donde se empiezan a controvertir las causas justificadoras — valga decir, originarias, genéticas- de la confrontación (Trejos, 2011, p. 132). En tal sentido, tratándose particularmente de conflictos de índole interno, se puede observar lineamientos políticos establecidos como patrones ideológicos o pilares que se proyectarán hacia la construcción de un nuevo sistema estatal, hecho que lleva a generar confrontaciones armadas contra el orden gubernamental establecido en determinado territorio. Al consolidarse circunstancias fácticas que posibilitan el desarrollo de conflictos de larga duración (desigualdad social, inconformidad estatal, escaso acceso a la justicia, etc.), dichos objetivos políticos, delimitados por marcos ideológicos inquebrantables, empiezan a matizarse por razones del mismo conflicto, ya sea para el mantenimiento de la confrontación bélica o las trasformaciones del mando militar o político de la organización insubordinada y del Estado (Barry, 1987, pp. 24-49; Trejos, 2008, pp. 20, 22), e incluso la coyuntura político-social internacional, lo cual permite encuentros entre las antiguas diferencias y las nuevas razones de encontrar espacios de deliberación en contextos de paz. Es así que los procesos armados, aun cuando durasen varias décadas o aquellos que poseen alta intensidad (estos más por razones humanitarias), encuentran caminos de negociación y elaboración de procesos, si bien no relativos a la materialización de la paz, al menos sí a la garantía de la dejación de armas.

De esta manera, aquellos espacios de construcción de reconciliación, y junto con ellos los procesos de sometimiento a la justicia, reparación a víctimas, consolidación de memoria histórica, restablecimiento de un orden normativo —o el llamado a la edificación de uno nuevo-, son objetivos fundamentales para ambas parte de la confrontación (Cortés, 2017), lo cual necesariamente implicará un grado de alto compromiso, tanto de la cadena de mando político-militar de la organización insubordinada como de las instituciones estatales, pues básicamente de ello dependerá el logro definitivo del cese al conflicto y, más aún, del cumplimiento de la «no repetición» (Muñoz, 2016, pp. 215, 217, 222).

Es así que, recopilando lo antecedido, nos encontramos en un espacio bilateral de plena voluntad política y militar para finalizar el conflicto armado (valga la aclaración, de carácter interno) dentro del cual una de las principales necesidades es la generación de un proceso de justicia que resuelva los crímenes devenidos del conflicto. Asimismo, es necesario precisar que existe una demanda social por el efectivo cumplimiento del fin jurídico de paz, justicia y seguridad, siendo este encontrado en la normativa constitucional y en el pronunciamiento popular (Squella, 2010, pp. 177, 185, 197; Accatino, 2019, p. 48). Finalmente, bien resaltan Delgado y Carnevali (2020) que el objetivo del sistema acusatorio de encontrar la verdad procesal no es exclusivo y, por tanto:

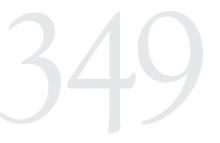

LA EXCULPACIÓN COMO CRITERIO

PUNITIVO FRENTE A DELITOS CONEXOS

A LA REBELIÓN

EN CONTEXTOS

DE CONFLICTO

ARMADO INTERNO:

UNA RELECTURA

DEL QUEHACER DEL

DERECHO PENAL

EN PROCESOS DE

PACIFICACIÓN

EXCULPATION

AS A PUNITIVE

CRITERIA AGAINST

CRIMES RELATED

TO REBELLION

IN CONTEXTS OF

INTERNAL ARMED

CONFLICT: A

REREADING OF

THE CRIMINAL

LAW WORK IN

PACIFICATION

PROCESSES 
el sistema acusatorio alcanza su pretensión, aun cuando no logre dilucidar la verdad absoluta, si se soluciona el conflicto y de esta forma se mantiene la paz social. Solución que, incluso, puede pasar por la no imposición de una pena, aunque el hecho históricamente sí sea un delito (p. 4) ${ }^{56}$.

Con esto entendido, es evidente la dificultad para encontrar un elemento que permita que aquellos delitos de carácter conexo al conflicto (no tratados por el DIH) se encuentren sumergidos en la necesidad especial y general propuesta por Roxín. Así, por un lado nos enfrentamos a miembros que participaron en el conflicto y que, junto a su cadena de mando - tanto la estatal como la insurgente-, se encuentran inmersos en un proceso de sometimiento ante la justicia (siendo este un vector prevalente del análisis conductual de la guerra no solo desde la punibilidad generada por el derecho interno, sino también desde el DIH), lo cual nos impide creer que los actos cometidos con anterioridad puedan ser supuestos de comisión a futuro. Esto se da incluso más cuando tratamos delitos conexos, pues estos se deben entender per se como inviables en el tratamiento punitivo de un proceso de paz, descartándose con ello la prevención especial ${ }^{57}$; y tampoco podemos establecer la atribuibilidad roxineana a dichos delitos cuando, a través de un proceso de paz validado normativa y socialmente, se reflejan los valores jurídicos presentados en el ordenamiento legal, siendo innecesaria desde una perspectiva preventiva general la imposición de sanciones penales que restablezcan este dominio normativo, pues la confirmación de un ordenamiento jurídico al que se someterán los actores del conflicto es inherente al proceso de paz (y no, por el contrario, a una rendición).

56 Situación que evidentemente no posee respuestas pacíficas, más al tratarse de un proceso de justicia transicional, razón por la cual la opinión concurrente del magistrado Diego García-Sayán para la sentencia del caso Masacres de El Mozote y lugares aledaños vs. El Salvador (2012) señala: «un conflicto armado y la solución negociada del mismo abre varios interrogantes y plantea enormes exigencias jurídicas y éticas en la búsqueda de la armonización entre justicia penal y paz negociada» (§ 26).

57 Para profundizar este argumento, debemos partir diciendo que los delitos conexos son aquellos que se trata de extraer de la necesidad preventiva especial, por cuanto acontecieron por y para el ejercicio del delito de rebelión, por lo que, una vez su continuación se vuelve innecesaria — producto del proceso transicional de paz-, también resulta innecesaria la acción estatal frente a la acometida de la resocialización de quienes cometieron dichos tipos penales. Paralelamente, a modo de ejemplo, los delitos proscritos por el DIH son evidentemente, por su carácter de «crímenes de guerra», supuestos que necesitan una conducción sancionatoria del delincuente, pues su fin no solo será imponer dicha pena a quien ejerció un delito internacionalmente vetado (necesidad preventiva general), sino también brindarle - a través de un sistema penal garantístico- condiciones de resocialización, factor último que permite demostrar la existencia, para faltas al $\mathrm{DIH}$, de la necesidad de la instrucción de prevención específica en sede de culpabilidad. 


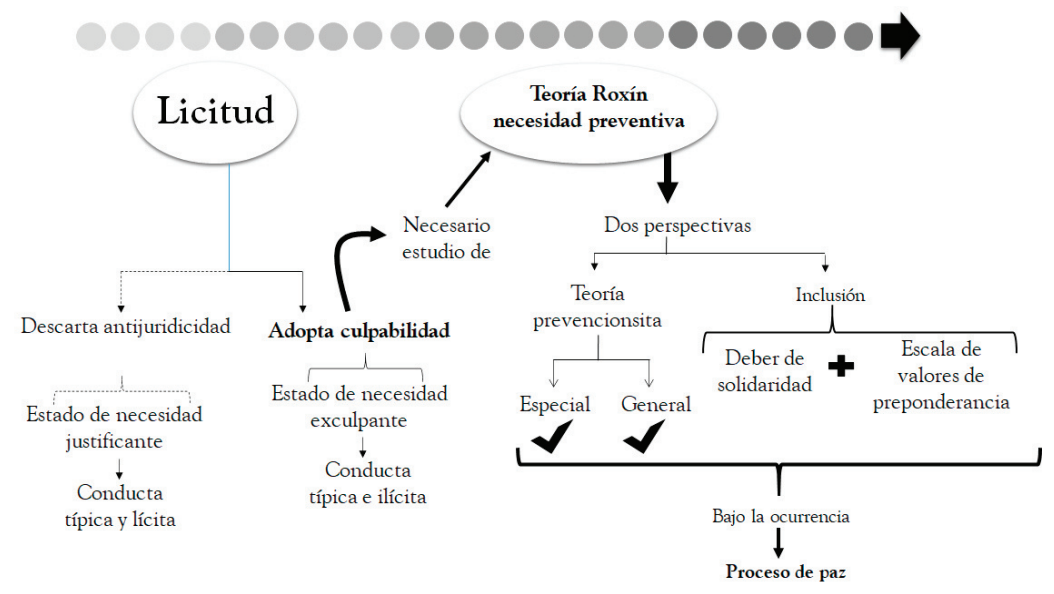

Fuente: elaboración propia.

Ahora bien, llegados a este punto, nos falta analizar la intromisión del deber de solidaridad y la escala de valores en los delitos conexos del conflicto armado interno, por lo que abordaremos con mayor claridad la justicia y la paz como fines del derecho y de la gran mayoría de las organizaciones estatales del mundo.

Así, el derecho a la paz, versado sobre la construcción social de la prohibición del uso de la fuerza ilícita, en donde los conflictos son resueltos a través de la fuerza legitimada por el ordenamiento jurídico (Squella, 2014, pp. 634-637), posee un vértice de doble cara, a saber: a) aquella que sostiene, dentro de un esquema de orden estatal, la necesidad de centrar la paz como justificante del orden social y finalidad del derecho; y b) aquella que busca, fuera del esquema estatal y a través del uso de la fuerza ilícita, el medio para el encuentro de una verdadera «justicia» y «paz». En tal sentido, la primera cara incluye el marco de fuerza prohibitiva y permitida como herramienta de búsqueda convencional de la paz, siendo esta debidamente determinada normativamente. No obstante, el centro de nuestra atención se colocará sobre la segunda cara del derecho a la paz, ya que este deviene de una construcción ajena a la base de un marco estatal y, en sí, proporciona un análisis crítico frente a la estructura institucional, normativa y de efectivo funcionamiento del Estado, siendo este espacio en donde con más claridad se percibe la unión analítica y directamente proporcional de la justicia con la paz (Travesí \& Rivera, 2016, pp. 2, 15-16).

Es menester señalar que es precisamente en este segundo ítem en el que se trasponen las razonabilidades asentadas en los fundamentos provenientes de la rebelión frente a los actos tiránicos e injustos, aun cuando estos representan dos coyunturas disímiles: hechos políticos

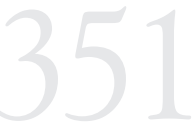

LA EXCULPACIÓN

COMO CRITERIO

PUNITIVO FRENTE A

DELITOS CONEXOS

A LA REBELIÓN

EN CONTEXTOS

DE CONFLICTO

ARMADO INTERNO:

UNA RELECTURA

DEL QUEHACER DEL

DERECHO PENAL

EN PROCESOS DE

PACIFICACIÓN

EXCULPATION

AS A PUNITIVE

CRITERIA AGAINST

CRIMES RELATED

TO REBELLION

IN CONTEXTS OF

INTERNAL ARMED

CONFLICT: A

REREADING OF

THE CRIMINAL

LAW WORK IN

PACIFICATION

PROCESSES 
tiránicos y desarrollo político tiránico (Negro, 1992, pp. 692-693). Así pues, podemos considerar en esta primera coyuntura la denominada ex defectu tituli ab origine o absque titulo generada a partir de la obtención de facto —o ilegítima - de la gobernanza de una comunidad, conllevando a la consolidación de un espectro de ilegitimidad del poder político. Por otra parte, la tiranía ex parte exercitii o ab exercitio hace referencia a un contexto político definido como válido por la comunidad, pero cuyas decisiones tiránicas se han tornado abusivas y, por ende, incompatibles del ejercicio justo del poder y la autoridad.

Con ello, desde estos dos parangones, Platón definiría como lícita la resistencia frente al tirano, estableciendo un «seudo derecho» de la sociedad a defenderse de dichas decisiones (De la Mora, 2005, p. 47); mientras que, posteriormente, autores como Isidro de Sevilla y Santo Tomás de Aquino (Cracogna, 1984, p. 167) sostuvieron que «cuando un régimen genera leyes injustas y gobierna con ellas para satisfacer a minorías, o en su propio beneficio, se transforma en ilícito y puede, por tanto, ser objeto de la rebelión» (Linares, 1984). Esta idea sería amoldada —en configuración de cuestionamiento- por San Agustín en el siglo IV, quien señaló en su obra La ciudad de Dios: «si de los gobiernos quitamos la justicia, ien qué se convierten sino en bandas de ladrones a gran escala?» (Martínez et al., 2014, p. 286).

Posteriormente, se establecería una visión más profunda en los estudios de John Locke, quien concebía al contrato social como una relación de confianza (Cortés, 2011, p. 128) en la que los individuos de una comunidad eligen un representante en quien centralizan su confianza y el poder general en favor del bien de la población, a diferencia de lo sostenido por Hobbes, quien, en busca de la neutralización total del «estado de naturaleza» — caracterizada por la famosa frase «el hombre es el lobo del hombre»-, postula un Estado regulador que brinda al «administrador-soberano» un poder ilimitado para legislar sobre la vida y la muerte de los individuos (Ramírez, 2010, p. 34). Locke, si bien concibe los peligros devenidos de dicho «estado de naturaleza», prevé en el gobierno de confianza el prevalecimiento de los derechos (aunque en dicho momento solo llegaban a ser prerrogativas) individuales de cada persona de la comunidad (garantizando la seguridad jurídica y salvaguardando fundamentalmente la garantía de la propiedad), cuya inobservancia hacía meritoria la actuación de reclamo que podía encontrarse junto con otros sentimientos de inconformismo, llegando en gran escala a ser asumidos como una rebelión (Biagini, 1978, p. 155) si esta se configura como reflejo de la voluntad general de la comunidad. En tal sentido, Locke (2005) señala de forma silogística que:

La finalidad del gobierno es el bien de la humanidad. [...] iY qué es mejor para la humanidad? ¿Que el pueblo esté permanentemente 
sometido a la voluntad irrestricta de la tiranía, o que los gobernantes estén expuestos, ocasionalmente, a que se les oponga resistencia, cuando el ejercicio de su poder se vuelve exorbitante y lo emplean en aras de la destrucción y no de la protección de las propiedades de sus súbditos? (pp. 254, 260).

Estas construcciones harían que posteriormente la Declaración de Independencia de los Estados Unidos y la Declaración de los Derechos del Hombre y del Ciudadano de la Revolución Francesa, ambas en la segunda mitad del siglo XVIII, permitiesen vislumbrar que las garantías ciudadanas obtenidas a través de ordenamientos jurídicos, las cuales a la postre reflejarían la paz, justicia y seguridad (como finalidades del derecho y de la organización estatal), pueden en su incumplimiento fundar conductas comprendidas como «autodestructivas» por el Estado, e incluso $-\mathrm{O}$, por ende - ser calificadas por el mismo como ilícitas, a pesar de que esconden un fundamento de legitimidad intrínseco en la misma consolidación de la organización social: la «resistencia a la opresión». Así las cosas, la Declaración de Independencia norteamericana precisaría que:

para garantizar estos derechos se instituyen entre los hombres los gobiernos, que derivan sus poderes legítimos del consentimiento de los gobernados; que cuando quiera que una forma de gobierno se haga destructora de estos principios, el pueblo tiene el derecho a reformarla o abolirla e instituir un nuevo gobierno que se funde en dichos principios, y a organizar sus poderes en la forma que a su juicio ofrecerá las mayores probabilidades de alcanzar su seguridad y felicidad.

La Declaración de los Derechos del Hombre y del Ciudadano de la Revolución Francesa, por su parte, consignaría en sus artículos 33, 34 y 35 que «la resistencia a la opresión» ${ }^{58}$ es «la consecuencia de los demás derechos del hombre», por cuanto «el gobierno viola los derechos del pueblo, la insurrección es, para el pueblo y para cada una de sus porciones, el más sagrado de los derechos y el más indispensable de los deberes», siendo por tanto dicho uso rebelde de la fuerza (valga recordar, en determinadas circunstancias) el camino, probablemente último, para salvaguardar la función de la justicia del derecho y, con esta, la integralidad de la paz.

Ahora bien, esta construcción social de adquisición de justicia, usando para ello mecanismos de fuerza fuera de la acción legal y dotando a su base justificatoria (o, si se quiere, de validez) en la legitimidad reflejada

58 Cabe recordar que en las sesiones del 20 al 25 de agosto de 1789, la Asamblea Constituyente francesa definió en el artículo 2 de la Declaración de los Derechos del Hombre y del Ciudadano que: «el objetivo de toda asociación política es la conservación de los derechos naturales e imprescriptibles del hombre. Estos derechos son la libertad, la residencia, la seguridad y la resistencia a la opresión» (traducción propia). Asimismo, ver Stevens et al. (2008, p. 127). 
en la sociedad en «resistencia», se ha impreso en el Preámbulo de la Declaración Universal de los Derechos Humanos de 1948, donde se expresa: "Considerando esencial que los derechos humanos sean protegidos por un régimen de Derecho, a fin de que el hombre no se vea compelido al supremo recurso de la rebelión contra la tiranía y la opresión».

Con lo antes mencionado, es necesario hacer referencia a Hannah Arendt de cara al análisis de la denominada «crisis de la República», quien precisa que la desobediencia civil ${ }^{59}$ se genera cuando un:

significativo número de ciudadanos ha llegado a convencerse, o bien, de que ya no funcionan los canales normales de cambio y de que sus quejas no serán oídas o no darán lugar a acciones ulteriores, o bien, por el contrario, de que el gobierno está a punto de cambiar y se ha embarcado y persiste en modos de acción cuya legalidad y constitucionalidad quedan abiertas a grandes dudas (Henao, 2006, pp. 70-76).

Es cierto, no obstante, que la desobediencia civil centra su finalidad en un nivel inferior a lo que representa la rebelión, puesto que hace mención a cualquier acto o proceso de oposición pública a una ley o una política adoptada por un Estado (Furfaro, 2013), mientras que la segunda tiene una connotación más estructural, siendo su nivel de trasformación mucho más profundo. A pesar de lo anterior, la desobediencia civil activa, así como la rebelión, precisan en su búsqueda de cambio frente a un acontecer injusto (cualquiera sea su índole) del uso gradual de la fuerza. Así, de llegar a ser consolidado argumentativamente el carácter justo de su actuar contrasistema, su acción fáctica se encontrará protegida no solo por el derecho internacional, sino también por gran parte de legislaciones nacionales que han rescatado taxativamente en sus cuerpos normativos el constructo histórico del uso de la fuerza legítima frente a una forma de gobierno injusto, incluso siendo este legal (Lucero, 2015, pp. 113-123, 126).

Así las cosas, hemos obtenido por un lado una acción de insubordinación que puede ser legitimada (lo cual dependerá esencialmente de las causas del conflicto y las dinámicas de la confrontación); y, por otro, delitos conexos que han sido puentes para la realización de conductas delictuales de mayor desvalor contra derechos individuales y colectivos, algunas incluso atentatorias del DIH (pero los cuales, como ya lo señalamos, no trataremos en el presente texto).

59 Entendiéndose dicha desobediencia civil como diferente de la desobediencia criminal, pues según Henao (2006, p. 10) la primera se caracteriza por ser a) un «desafío abierto» —valga decir, público, de la ley-, b) una actuación «en nombre y beneficio de un colectivo social» y c) un desafío a «la ley sobre el fundamento de un disentimiento básico»; mientras que la desobediencia criminal requiere de a) una «Violación oculta de la ley», b) «actúa en nombre y beneficio propio», y c) «desafía la ley con el deseo de beneficiarse individualmente» o con un carácter restringido de individualismo a un grupo determinado. 
Pues bien, hemos de afrontar la problemática, primero, mediante la escala de valores que nos permitirá desarrollar una medición valórica de males, enfrentando aquel mal destinado a ser evitado (que en este caso sería, desde la perspectiva de la organización insubordinada, la continuación de un régimen político injusto) con aquel mal causado (los delitos conexos en los conflictos armados internos en el marco de procesos de paz). En segundo lugar, definiremos el grado del déficit motivacional y la probabilidad de provocación que encaucen los delitos conexos en la falta de reprochabilidad a través del EN exculpativo.

De tal forma, el resultado frente al primer ítem no puede ser otro que el hallar en ambos males intereses jurídicos valóricos muy por encima del «nivel medio de equivalencia», lo cual generará la integración de dichos delitos, por su preponderancia y cercanía el uno con el otro, bajo el manto de un EN exculpante en donde el Estado no alcanza el nivel de reprochabilidad suficiente desde la culpabilidad para exigir la consagración de un delito. Ahora, en cuanto los delitos conexos en un conflicto armado interno que surca un proceso de justicia transicional (no incurso aquellos vulneradores del DIH o graves violaciones al DIDH), por los razonamientos ut supra señalados en relación a la ausencia de prevención roxineana general y específica, así como al des-enlazamiento de los actos conexos con la rebelión cuando esta es reconocida en un proceso de paz, y siendo a su vez dicha actuación cobijada como una garantía también democrática del ejercicio ciudadano, consideraremos que aquel de mayor preponderancia será, bajo los estipulados anteriores, el «mal causado».

Figura $N^{\circ}$ 9. Nivel de preponderancia vs. EN exculpante

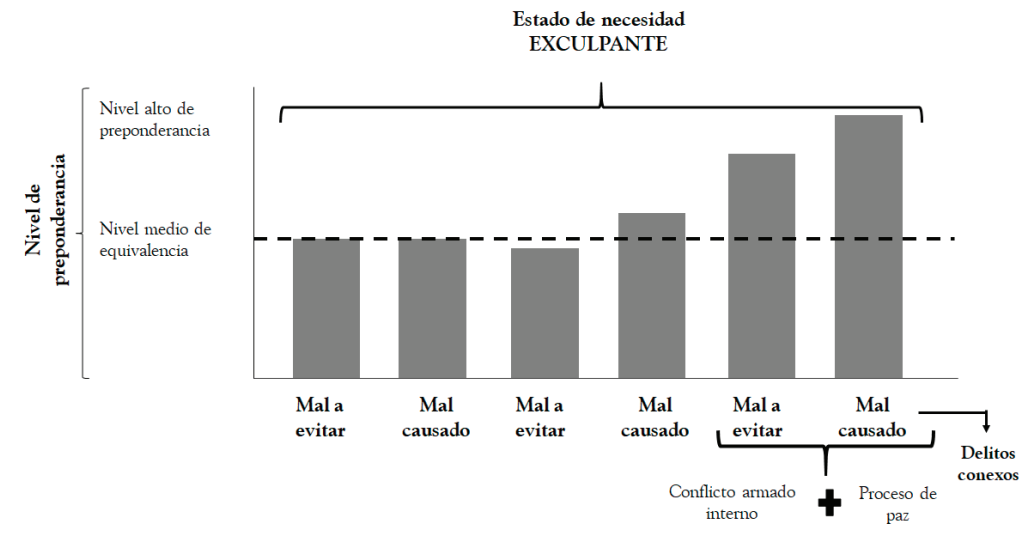

Fuente: elaboración propia.

Por su parte, el déficit motivacional proviene justamente del carácter subjetivo existente entre la comisión de los delitos conexos y el resultado de salvaguarda de los intereses — surtidos por la rebelión — causantes

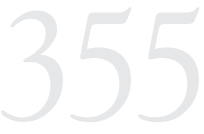

LA EXCULPACIÓN COMO CRITERIO

PUNITIVO FRENTE A

DELITOS CONEXOS

A LA REBELIÓN

EN CONTEXTOS

DE CONFLICTO

ARMADO INTERNO:

UNA RELECTURA

DEL QUEHACER DEL

DERECHO PENAL

EN PROCESOS DE

PACIFICACIÓN

EXCULPATION

AS A PUNITIVE

CRITERIA AGAINST

CRIMES RELATED

TO REBELLION

IN CONTEXTS OF

INTERNAL ARMED

CONFLICT: A

REREADING OF

THE CRIMINAL

LAW WORK IN

PACIFICATION

PROCESSES 
de la exculpación, siendo el EN en sí mismo un hecho evidente en la confrontación armada que, sin embargo, encuentra discusión en su grado de autoprovocación. En este punto, nos enfrentaremos a dos respuestas: la primera, dirigida a aceptar un nivel de creación de la situación de peligro; y la segunda, que admite esta circunstancia como causante del EN exculpante.

En la primera perspectiva, nos encontramos con autores como Esteban Righi y Cerezo Mir, que determinan que el imputado «debe ser extraño a la creación de la situación de peligro» (Gómez Huilca, 2017, pp. 42-43), entendiendo esto como el accionar del sujeto como un factor apartado de la razón principal de causación; mientras que Maurach, Zipf y Roxín —cuyas tesis seguiremos—consideran irrelevante que un sujeto invoque la causal de necesidad que fue provocada tanto por el autor como por el titular del bien a salvar (Donna, 2008, p. 331; Gómez Huilca, 2017, p. 42), pues solo la sede de estudio para la acogida del EN se encuentra en discusión (valga decir, antijuridicidad o culpabilidad), mas no el EN en sí mismo.

Por otro lado, dicho EN debe enfrentar un doble examen, tanto de ponderación extensiva de intereses (que verifique su ubicación exculpante) como del grado de apropiabilidad colectiva o del grado motivacional frente al resultado finalmente generado. Así las cosas, la acción tiene cobijo exculpatorio siempre que el bien a salvar goce de una valoración social considerable frente al bien a sacrificar (Donna, 2008, p. 287), cuya justificación se haya en el mismo contexto de un proceso de paz que está cimentado en esta necesidad colectiva de surtir dichas cesiones ante los intereses jurídico-penales vulnerados a través de la comisión, en este caso, de los delitos conexos.

Con esto dicho, la teoría exculpatoria de delitos conexos en conflictos armados internos sujetos a procesos de paz queda concluida, no sin antes prever algunos espacios problemáticos que debemos resolver.

\section{V.LOS BACHES EN LA PROPUESTA}

Bien sabemos que la sola aceptación doctrinal de los estados de necesidad y su ubicación en la teoría del delito son discusiones que aún no poseen resolución unilateral, pero debemos ser claros al reconocer que en el caso de una teoría que trata con herramientas teóricas, modificar escenarios punitivos de confrontación armada es una actividad todavía más problemática.

En tal medida, resolveremos preguntas necesarias que ayudarán a dar más fortaleza a la propuesta presentada en el presente texto. 
1. ¿Podríamos asumir el tratamiento de los delitos conexos desarrollados en la propuesta del texto como un estado de necesidad provocado? Actualmente, gran parte de la doctrina considera de manera correcta que para que se genere el efectivo acontecimiento de un EN es necesario, entre otras cosas, que no haya sido provocado intencionalmente por el actor que sufre dicho «estado» ${ }^{60}$. Ahora bien, esta premisa se basa en la fuente genérica de los EN; es decir, la existencia de un «estado» anormalizado normativamente, con baseen el cual elEstadoesindulgente en lailicitud (EN justificante) o culpabilidad (EN exculpante) del actuante. Como pudimos observar anteriormente, el actuar insubordinado —entiéndase, rebelde - tiene bases tanto filosóficas como jurídicas en la misma estructura estatal, por lo que la rebelión o la desobediencia civil no es un espacio que se surte per se, sino un derecho que se ejerce cuando existen justificaciones político-sociales (Lucero, 2015, pp. 129-130; Carvajal, 1992, pp. 93-101). Al ser protegido dicho ejercicio volitivo por el mismo sistema normativo, resulta contraproducente pensar que a la par sea también una conducta que por el hecho de ejercerse tendrá una eliminación de facto de sus constructos justificatorios, haciéndola por ello una acción de mera connotación delictual y no un ejercicio político-social. Ahora bien, la finalidad de la insubordinación presentada en un conflicto armado interno (prevista en el artículo 1 del Protocolo II de los Convenios de Ginebra) no radica en solicitar la aparición de un EN exculpante en un proceso penal ordinario, lo cual elimina nuevamente de facto las situaciones justificatorias - sede de antijuridicidad - de la insubordinación; sino, por el contrario, en la trasformación de un sistema político cuya finalidad, sea buena o mala (o, en otras palabras, más o menos acorde al DIDH, lo cual no es objeto de discusión en este texto, sino la valoración político-criminal de los delitos conexos), es permitida en las mismas bases filosóficas de nuestros sistemas republicanos de Estados-nación. Por todo lo anterior, debemos descartar la provocación del EN, en este caso exculpante, de aquellos delitos conexos a la rebelión, pues dicha circunstancia hipotética no guarda coherencia con la asunción de un conflicto armado y el desarrollo de un proceso de paz que, por sí mismos, proponen las actuaciones beligerantes como consecuencias de una causa común, si se quiere, provocada por el Estado - entre otros- y que debe ser resuelta ${ }^{61}$. Con ello también debemos asumir que se

60 Como lo sostendría la corriente finalista, siendo el mayor de sus exponentes Welzel. Para este tema, ver Schünemann (1991, pp. 54, 56).

61 Ello analizado desde las teorías del riesgo creado, la posición de garante del Estado y, en sí, de la acción u omisión de una autoridad pública que compromete al Estado con sus resultados, generándose incluso en procesos de responsabilidad un contenido de imputabilidad, más allá de la mera causalidad (Ángel, 2015, pp. 23-29).

LA EXCULPACIÓN

COMO CRITERIO

PUNITIVO FRENTE A

DELITOS CONEXOS

A LA REBELIÓN

EN CONTEXTOS

DE CONFLICTO

ARMADO INTERNO:

UNA RELECTURA

DEL QUEHACER DEL

DERECHO PENAL

EN PROCESOS DE

PACIFICACIÓN

EXCULPATION

AS A PUNITIVE

CRITERIA AGAINST

CRIMES RELATED

TO REBELLION

IN CONTEXTS OF

INTERNAL ARMED

CONFLICT: A

REREADING OF

THE CRIMINAL

LAW WORK IN

PACIFICATION

PROCESSES 
daría respuesta a la «falta de posibilidad de actuar diferente» ${ }^{62}$ y al «conocimiento del riego dañoso» (Schünemann, 1991, pp. 54, 56) exigidos por la culpabilidad.

2. Frente a los delitos conexos en un conflicto armado, icómo se tendría certeza de que existe una superioridad considerable del nivel medio de equivalencia (ver figura 9)? En primer lugar, podemos afirmar que cada uno de los conflictos armados posee sus particulares diferencias, ya sea en los elementos justificatorios del mismo como en las acciones político-militares desarrolladas, lo cual dependerá en gran medida del territorio en el que se gesta la confrontación armada y del tamaño de la población que legítima la insubordinación. De esta forma, arribar a que el «mal causado» deberá siempre presentarse como más relevante jurídicamente que el «evitado» en la escala de preponderancia de los delitos conexos de la figura 9 es una cuestión de correlación de situaciones que, una vez dadas, originan procesos de paz y de justicia transicional, pues de estos espacios es que surge la justificación políticasubjetiva que reivindica jurídicamente ${ }^{63}$ (aunque no totalmente, pues entraríamos a escenarios de indulto o de amnistía) como un derecho la rebeldía ante la injusticia estatalizada (Trejos, 2011, p. 138; Travesí \& Rivera, 2016, p. 2), aun cuando no se afirme con certeza absoluta que dichos ideales y contextos arbitrarios encuadran en lo que teórica y normativamente se desprende del entendimiento de desobediencia civil o rebelión. Correlativamente, de no establecerse un sistema jurisdiccional especial para el tratamiento transicional de los delitos devenidos del conflicto armado interno, es predecible concebir un tenso apuro en tanto el relativismo de la percepción punitiva que puede tener un juez o una jueza, si bien ya está inmerso o inmersa en un proceso transicional, puede virar de un EN exculpante a uno de atenuación sancionatoria preponderante (ver figura 7). Lo anterior podría tener una solución acorde a un sistema tasado de prevalencias o preponderancias en el que no exista duda de los tipos penales cobijados en la conexidad a la rebelión durante dicho proceso de paz, no siendo óbice para que se incluyan otros siempre que no se encuentren inmersos en las prohibiciones (si

62 Frente a este entendido, Silva (1992) expone: «La doctrina de base finalista partía de entender que en las causas de exclusión de la culpabilidad (vgr. la inimputabilidad) le faltaba al sujeto el poder actuar de otro modo» (p. 410). En tal sentido, entre las varias «causas de exculpación o de disculpa (Entschuldigungsgründe)» se genera una «disminución de la culpabilidad (del poder actuar de otro modo), debida a la presión psíquica externa, junto a una disminución del injusto, debida a la orientación objetiva de la conducta a la salvaguarda de bienes jurídicos. La doble disminución de injusto y culpabilidad propiciaría la "disculpa" global del hecho, esto es, la renuncia por el estado a la imposición del resto de pena» (p. 411).

63 En tal sentido, Muñoz Conde (1985) señala que «es la sociedad, o mejor la correlación de fuerzas sociales existente en un momento histórico determinado, la que define los límites de lo culpable y de lo inculpable, de la libertad y de la no libertad» (p. 63). 
se quiere, también valóricas) de exculpación (y, más aún, de justificación) de aquellos vulneratorios del DIH, o que generen grave afectación al DIDH ${ }^{64}$.

3. Acudiendo a las tesis que encuentran en el libre albedrío el elemento fundador de la culpabilidad, en tanto sin esta no es posible un reproche penal, ila consideración del EN exculpante no es una propuesta reforzada para dar solución a dicho inconveniente político-criminal? Es cierto admitir que el reproche de culpabilidad se concibe, además de desde las tesis prevencionistas de Roxín, desde la arista de la corroboración de la libertad del agente agresor, cuyo eje se estipula en la idea del «poder actuar de otro modo» ${ }^{65} \mathrm{y}$, por tanto, en el cuestionamiento de poder o no haber evitado el hecho imputado (Rodríguez, 2017, p. 115).

Con todo, dicha libertad no es vislumbrada desde la abandonada «relación psicológica entre el sujeto y la acción» (culpabilidad en cuanto dolosa o culposamente el actor ejercitó el injusto), sino desde una concepción normativa de la culpabilidad (Welzel, 1980). De acuerdo a esta, se concibe la ejecución de la pena con un sentido finalista, aun cuando cobra renovada importancia el denominado «neorretribucionismo» ${ }^{66}$, en donde la misma no puede ser impuesta al actor si este no tuvo la capacidad para decidirse libre y correctamente entre el derecho y la injusticia (Wessels, 1980, p. 109) ${ }^{67}$, pues, como bien afirmaba Hassemer (1984), «sin libertad de voluntad no hay alternativas

64 Aunque esto podría generar complejos debates, por ejemplo, en cuanto al delito de narcotráfico. Claro, ello dependerá del grado de aceptabilidad y reconocimiento del acto rebelde, así como de la política criminal frente al tráfico de estupefacientes.

65 Así las cosas, Maier (1978) configura la coexistencia entre la libertad del ciudadano o la ciudadana en sus decisiones y el sustento «del reproche al autor de haber podido obrar de otra manera al conocer o haber podido reconocer potencialmente la criminalidad de su acción» (p. 301).

66 Devenido del movimiento de law and order, Künsemüller (2001) lo describe en el sentido de que «no reiteran el discurso original sobre realización de la justicia absoluta, pero, en cambio, califican a la retribución jurídica como equivalente al principio de proporcionalidad» (p. 146); esto es, «la proporción estricta entre la cuantía de la sanción y la gravedad de la ofensa, entre medida de la pena y grado de la culpabilidad» (p. 146). Por tanto, en colorario, buscan un «Derecho Penal mejor (lo que significa un Derecho Penal más duro), no algo mejor que el Derecho Penal» (p. 145).

67 Existe en este punto un arduo debate entre la afirmación del determinismo o el indeterminismo, lo cual, lejos de ser baladí, repercute en la fundamentación filosófica de la reprochabilidad penal. Ante esto, es importante recordar lo señalado por Carrara (2000), quien precisaba: «Yo no me ocupo de cuestiones filosóficas, por lo cual presupongo como aceptada la doctrina del libre albedrío y de la imputabilidad moral del hombre y como asentada sobre esa base la ciencia criminal, que mal se constituiría sin aquella» (p. 32), lo cual tiene inmenso sentido, siendo lo contrario negar la posibilidad de establecer la culpabilidad a todo injusto. En ese sentido, Künsemüller (2001) considera que ni el determinismo ni su opuesto pueden ser científicamente comprobados, por lo que «el derecho penal debe darse por satisfecho con el reconocimiento de que el principio de responsabilidad del hombre moralmente maduro y psíquicamente sano constituye una realidad irrefutable en nuestra existencia social» (p. 158). Frente a este punto, ver Wessels (1980, p. 109). Finalmente, Cárdenas Aravena (2008) bien señala la necesidad del principio de culpabilidad (pues este se instituye como la última "garantía para el ciudadano en un Estado de Derecho») frente la alternativa —contemporánea— de la responsabilidad penal objetiva o la responsabilidad penal por peligrosidad; por tanto, la «culpabilidad debe ser aceptada como una ficción necesaria» (pp. 83-84).

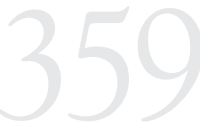

LA EXCULPACIÓN COMO CRITERIO

PUNITIVO FRENTE A

DELITOS CONEXOS

A LA REBELIÓN

EN CONTEXTOS

DE CONFLICTO

ARMADO INTERNO:

UNA RELECTURA

DEL QUEHACER DEL

DERECHO PENAL

EN PROCESOS DE

PACIFICACIÓN

\section{EXCULPATION}

AS A PUNITIVE

CRITERIA AGAINST

CRIMES RELATED

TO REBELLION

IN CONTEXTS OF

INTERNAL ARMED

CONFLICT: A

REREADING OF

THE CRIMINAL

LAW WORK IN

PACIFICATION

PROCESSES 
de comportamiento y sin alternativas de comportamiento no hay reproche de culpabilidad» (p. 283).

Así las cosas, es posible proponer que la libertad, transformada en el estudio del «libre albedrío» inmerso en la culpabilidad ${ }^{68 / 69}$, tenga el potencial de inimputabilidad al existir coacción en la realización de tipos penales. Por tanto, es posible que los y las ciudadanas rebeldes en situación de reclutamiento forzado, habiendo participado en el conflicto armado ejecutando delitos conexos (no incluyéndose, o como mínimo, estando en arduo debate aquellos atentatorios al DIH y gravosos al DIDH), puedan considerarse dentro del estudio de la teoría del delito como si sus acciones no estuvieran cubiertas de culpabilidad a causa del miedo insuperable atentatorio del libre albedrío del imputado ${ }^{70}$, e incluso, en ciertos escenarios, que se depreque la inimputabilidad de sus actos (cuando, verbigracia, se encuentran bajo observación penal los combatientes menores de 14 años) ${ }^{71}$. No obstante lo

68 A dicha inescindible conexión hace referencia Gonzalo Fernández (1995) al considerar que «la posibilidad de construir un concepto de culpabilidad penal, y en último término, de edificar sobre ella el contenido de la responsabilidad criminal, está ligada a la eterna cuestión metafísica de la libertad humana» (p. 137), lo que remata Muñoz Conde (1981) al decir: «es la sociedad, o mejor la correlación de fuerzas sociales existente en un momento histórico determinado, la que define los límites de lo culpable y de lo inculpable, de la libertad y de la no libertad» (p. 28). Ver también Rodríguez (2017, p. 112).

69 Aun cuando es importante aclarar las posiciones críticas a la real posibilidad de comprobación de libre albedrío, esto implicaría como base la existencia (fundamentalmente desde la antropología) de «un ser idóneo para autodeterminarse conforme a criterios normativos, un sujeto dotado de racionalidad y atribuciones de comportamiento alternativo, un individuo capaz de escoger y decidir entre conductas diversas, de distinto significado frente al Derecho» (Künsemüller, 2001, p. 155), por lo que, al no comprobarse dichas características, no podría ser posible un juicio de reproche.

70 Es interesante cómo Marinucci y Dolcini (2009, pp. 256, 267, 327) proponen -aunque desde la tesis monista del EN, existente solo en sede de antijuridicidad- la falta de responsabilidad del agente cuando existen constricciones suficientes para quebrantar su libertad. En esta medida, dicho «turbamiento psicológico que lo constriñe a actuar» genera que este sacrifique «un bien de un tercero para evitar un peligro propio o ajeno que amenace dañar su persona» (Uribe, 2012, p. 7). En el mismo sentido, Zaffaroni (2018) considera que «la coacción (que puede provenir tanto de la conducta de un tercero como de hechos de la naturaleza) [...] puede dar lugar a un estado de necesidad justificante o a uno exculpante, según la magnitud del mal que amenaza al coaccionado y del que éste causa» (p. 58). Finalmente, Guerra (2020) señala que «El estado de necesidad por coacción generalmente es definido como una excusa, porque el razonamiento del agente se encuentra en una posición injusta en la elección. La regulación del estado de necesidad no establece dicha preferencia como justificada, porque la acción viola intereses de mayor entidad que pueden afectar incluso la vida de terceros» (p. 21). Por todo, esta sería, aunque por otro camino y para un sector reducido de un grupo beligerante de un conflicto armado, una salida óptima a través del EN exculpante.

71 En el ámbito internacional existe un punto crítico en el rango posterior a los 14 años, pues las reglas de Beijing (§§ 16.1; 17.1, literal a-c; 17.2) y las directrices de Riad (§§ I.1, VI.56), expresan la capacidad que tienen las personas menores de 18 (y mayores de 14) para cometer una conducta típica, antijurídica y culpable. No obstante, como bien afirman Latorre et al. (2018), dicha imputabilidad significa «afirmar la responsabilidad penal o concluir la necesidad de una penalización de conductas cometidas por este grupo poblacional» (p. 41), ya que se requiere que el sujeto pasivo del poder penal sea "consciente del carácter ilícito del comportamiento» y decida «actuar en contravía del sistema normativo, en condiciones en las cuales podía encaminarse hacia la legalidad» (p. 41). Ahora bien, en aquellos casos en los que los combatientes reclutados son personas menores de edad, y continuaron siendo parte del grupo insurgente una vez superada su minoría etaria (y, por tanto, cometiendo acciones típicas), según la jurista colombiana Juliana Diaz (2019, pp. 580-583) se consolida como una suerte de "arbitrariedad» la situación reprochable de aquellos combatientes ( "teoría de la aleatoriedad»), en la que el ejercicio volitivo ha sido desde su raíz coaccionado hacia la comisión de ilícitos, siendo conexa una calidad dual de víctimas del conflicto ante la situación fáctica que los ha puesto en ese escenario criminológico. Por tanto, afirma la jurista, es de mayor valor el 
anterior, a pesar de ser válida la encuadernación de los elementos penales para los exclusivos casos de reclutamiento forzoso, la misma no alberga una solución generalizada para el grueso de combatientes que ejercitan la rebeldía, quienes, como hemos previsto, tienen — en un contexto de justicia transicional — una solución prevista en la institución del EN exculpante.

4. iAun cuando el desarrollo de un proceso de pazjustifique en gran parte la ausencia de prevención general e individual para los delitos conexos, podemos eliminar per se el carácter de peligrosidad de los actos? Para esta última grieta deberemos recurrir a lo precisado por el doctrinante Jesús María Silva (1992), quien —añadiéndose a Amelung - manifiesta la posibilidad político-criminal de que al excluir la culpabilidad, se excluya asimismo la peligrosidad. De tal forma, en aquellos casos en los que se realiza dicha exclusión, se repele la aplicación «tanto de penas como de medidas de seguridad», y en aquellos casos en los que no, se deja abierta la posibilidad de establecer dichas medidas debido a que subsiste la «necesidad de reacciones preventivo-especiales» (p. 411). A partir de ello, Silva destaca que en aquellos casos en los que:

impiden incluso la imposición de medidas excluirían la imposición de toda reacción jurídico-penal, lo que las mostraría como causas de más amplia trascendencia, al eliminar también la consideración del delito como manifestación de una «peligrosidad» del autor. Esto situaría a estas causas más cerca de las de exclusión del injusto penal (p. 411).

En este entendido, podemos considerar que el contexto de confrontación armado, y el consecuente proceso de paz como un escenario de resolución del mismo, deben ser vislumbrados como causas de indiscutible trascendencia, las cuales se verían reflejadas en el interés político de toda la sociedad de llegar a una resolución pacífica del conflicto y en la no repetición del mismo. Esta proyección, por tanto, será reflejada en aquellos delitos conexos que, si bien surtieron gran importancia en el desarrollo de la confrontación armada y la comisión de actos ilícitos, pueden ser superados tras teorías político-criminales, siempre que se excluyan bajo este panorama resolutivo los cometidos contra el DIH. Por ello, la óptica de falta de peligrosidad es incluyente para todos los delitos conexos cometidos por todos los miembros de la organización beligerante, siendo su límite los ilícitos ocasionados en vulneración del DIH pues estos, en su análisis jurisdiccional

LA EXCULPACIÓN

COMO CRITERIO

PUNITIVO FRENTE A

DELITOS CONEXOS

A LA REBELIÓN

EN CONTEXTOS

DE CONFLICTO

ARMADO INTERNO:

UNA RELECTURA

DEL QUEHACER DEL

DERECHO PENAL

EN PROCESOS DE

PACIFICACIÓN

EXCULPATION

AS A PUNITIVE

CRITERIA AGAINST

CRIMES RELATED

TO REBELLION

IN CONTEXTS OF

INTERNAL ARMED

CONFLICT: A

REREADING OF

THE CRIMINAL

LAW WORK IN

PACIFICATION

PROCESSES 
de la teoría del delito en sede de culpabilidad, sí representan la peligrosidad visionada en la necesidad preventiva general y especial roxineana.

5. ¿Cuáles son los mínimos para considerar la existencia real de un proceso de paz que permita la aplicabilidad de la teoría de exculpación frente a delitos conexos al conflicto? Considerando lo anterior, deberemos entender como mínimos fácticos para la aplicación plena de esta teoría exculpatoria de los delitos conexos lo siguiente: a) la existencia real de un escenario de pacificación (confrontado, verbigracia, con el cese bilateral armado y la confluencia de actores internacionales que velan por el continuo desarrollo del proceso de paz, entre otros elementos); b) el establecimiento de garantías políticas como económicas que impidan el continuo ejercicio de los delitos conexos, aun cuando la rebelión haya sido evacuada a través del reconocimiento legitimatorio de los rebeldes mediante un proceso de paz ${ }^{72}$; y, finalmente, c) finalmente, la configuración o construcción de un acuerdo especial de paz con recubrimiento constitucional que impida su modificación con el fin de imposibilitar la repetición —al menos normativamente- de las motivaciones específicas que dieron nacimiento al conflicto.

\section{VI.PALABRAS FINALES}

Como bien dijimos al comienzo de este texto, la misión del jurista es salvaguardar los pilares jurídico-filosóficos del derecho penal como herramientas que faciliten y, por tanto, no entorpezcan el ámbito fáctico de obtención de derechos. Los conflictos armados de carácter interno son escenarios que seguirán ocurriendo en todo el mundo, cuya resolución pasa por elementales cambios de hegemonía política y efectiva tutela de derechos por parte de los Estados, pues en aquellos hechos, en gran parte de ocasiones, se encuentran las causas más notables de las confrontaciones beligerantes. Así, la propuesta plasmada en este artículo permite que, en el marco de un proceso de paz, el conflicto se vuelque en la resolución juiciosa de procesos jurisdiccionales en los que se ha vulnerado el DIH, y que desde esta parta también el vislumbramiento de los cambios estructurales que los Estados actuales deben surtir en

72 De no brindarse dichas garantías, el proceso se hace objeto de un probable contexto fáctico en el que se siguen cometiendo delitos conexos, los cuales se han convertido en el modus vivendi que financia la subsistencia de los miembros del grupo insurgente (verbigracia, narcotráfico, secuestro, extorsión) (Lucero, 2012, pp. 26-27). Ello, además, nos ubicaría en un escenario en el que se debería afrontar predicamentos teóricos frente a la naturaleza misma de los delitos conexos, todos estos basados en la duda de que la rebelión fuese la causa de dichos delitos y, por tanto, posibilitando la afirmación de que estos se proyecten como independientes, generando que o bien se juzguen fuera de las reglas establecidas en un proceso de justicia transicional, o generen la expulsión del o los ciudadanos rebeldes del proceso transicional, siempre que incumplan con los mandatos posconflicto de no comisión de actos ilícitos. Ejemplo de esto último es observable en el proceso Santrich — ver Corte Suprema de Justicia (2019) y Ámbito Jurídico (2019) — de la Jurisdicción Especial de Paz colombiana. 
su misión social, antes que en pro de su interés económico particular, poco o nada reflejado en el bienestar colectivo. Por lo expuesto, concluimos que la institución de la exculpación de los delitos conexos al conflicto implica tan solo el «engrasamiento» de un proceso de paz y una deliberación jurídica que debe volcarse con mayor fortaleza en otros ítems que permitan el sostenimiento de un sistema real de justicia y paz colectiva, siendo este el material fundamental — y no los ejércitos— que evitará la repetición de conflictos.

\section{REFERENCIAS}

Accatino, D. (2019). ¿Por qué no a la impunidad? Una mirada desde las teorías comunicativas al papel de la persecución penal en la justicia de transición. Política criminal, 14(27), 47-64. https://doi.org/10.4067/s0718-33992019000100047

Ámbito Jurídico (2019). Este es el abecé del caso penal y transicional de 'Jesús Santrich'. Recuperado de https://www.ambitojuridico.com/noticias/penal/electoral/este-esel-abece-del-caso-penal-y-transicional-de-jesus-santrich

Ángel Müller, C. N. (2015). Responsabilidad del Estado por el conflicto armado: iimputación o causalidad? Bogotá: Universidad del Rosario, Facultad de Jurisprudencia.

Armaza Galdós, J. (2009). Estado agresivo y defensivo de necesidad. En J. Hurtado Pozo (ed.), Problemas fundamentales de la Parte General del Código Penal (pp. 284329). Perú: Universidad de Friburgo, Fondo Editorial PUCP.

Armaza Galdós, J. E. (2014). El estado de necesidad justificante. Biblioteca Virtual Miguel de Cervantes. Recuperado de http://www.cervantesvirtual.com/obra/elestado-de-necesidad-justificante/

Bacigalupo, E. (2005). Derecho penal y el Estado de derecho. Santiago de Chile: Jurídica de Chile.

Barry, D. (1987). Los conflictos de baja intensidad. El caso de Centro América. Costa Rica: CRIES.

Benítez Caorsi, J. J. (2005). El estado de necesidad en la responsabilidad civil. Revista Latinoamericana de Derecho, 2(4), 27-55.

Biagini, H. E. (1978). El "ius resistendi" en Locke. Revista de Estudios Políticos, (2), 153-160.

Bustos Ramírez, J. (1991). Manual de derecho penal, Parte especial (2da edición). Barcelona: Ariel.

Bustos Ramírez, J. J. (2005). Antijuricidad y causas de justificación. Nuevo Foro Penal, (67), 54-60.

Bustos Valderrama, C. (2004). Estudio del artículo tercero del Convenio de Ginebra de 1949, relativo a la protección de personas civiles en tiempo de guerra,

LA EXCULPACIÓN COMO CRITERIO PUNITIVO FRENTE A DELITOS CONEXOS A LA REBELIÓN EN CONTEXTOS DE CONFLICTO ARMADO INTERNO: UNA RELECTURA DEL QUEHACER DEL DERECHO PENAL EN PROCESOS DE PACIFICACIÓN

\section{EXCULPATION}

AS A PUNITIVE

CRITERIA AGAINST

CRIMES RELATED

TO REBELLION

IN CONTEXTS OF

INTERNAL ARMED

CONFLICT: A

REREADING OF

THE CRIMINAL

LAW WORK IN

PACIFICATION

PROCESSES 
y del Protocolo adicional II de 1977. Revista de Derecho del Consejo de Defensa del Estado, (12), 67-87.

Cárdenas Aravena, C. M. (2008). El principio de culpabilidad: estado de la cuestión. Revista de Derecho, 15(2), 67-86. https://doi.org/10.22199/ s07189753.2008.0002.00003

Carranza Piña, J. (2011). La inculpabilidad y exigibilidad penal. Bogotá: Universidad Nacional de Colombia.

Carrara, F. (2000). Programa del Curso de Derecho Criminal (vol. I). Costa Rica: Instituto latinoamericano de las Naciones Unidas para la Prevención del Delito y el Tratamiento del Delincuente.

Carvajal Aravena, P. (1992). Derecho de resistencia, derecho a la revolución, desobediencia civil. Revista de Estudios Políticos (Nueva Época), (76), 63-101.

Castillo Morales, J. P. (2016). El estado de necesidad del artículo $10 \mathrm{n}^{\circ} 11$ del Código penal chileno: ¿Una norma bifronte? Elementos para una respuesta negativa. Revista Política Criminal, 11(22), 340-367. https://doi.org/10.4067/ s0718-33992016000200001

Cerezo Mir, J. (1981). La doble posición del dolo en la Ciencia del Derecho Penal española. Anuario de derecho penal y ciencias penales, 34 (2-3), 455-460.

Cerezo Mir, J. (2000). Curso de derecho penal español. Parte General. España: Tecnos.

Cerezo Mir, J. (2009). La influencia de Welzel y del finalismo, en general, en la Ciencia del Derecho penal española y en la de los países iberoamericanos. Anuario de derecho penal y ciencias penales, 62 (1), 67-92.

Comité Internacional de la Cruz Roja. (2010). Los Convenios de Ginebra de 1949 y sus Protocolos adicionales. Recuperado de https://www.icrc.org/spa/war-and-law/ treaties-customary-law/geneva-conventions/overview-geneva-conventions.htm

Comité Internacional de la Cruz Roja. (2011). El derecho internacional humanitario y los desafíos de los conflictos armados contemporáneos. En XXXI Conferencia Internacional de la Cruz Roja y de la Media Luna Roja celebrada en Ginebra. Recuperado de https://www.icrc.org/es/download/file/15128/32icreport-on-ihl-and-the-challenges-of-armed-conflicts_es.pdf

Comité Internacional de la Cruz Roja (2016). ¿Qué dice el DIH sobre los acuerdos especiales en el marco de un proceso de paz? Recuperado de https://www.icrc.org/ es/document/acuerdos-especiales-acuerdos-de-paz-dih-colombia-comentariosconvenios-de-ginebra

Correa Flórez, M. (2016). Legítima defensa en situaciones sin confrontación: la muerte del tirano de casa. Madrid: Universidad Autónoma de Madrid. https://doi. org/10.15425/2017.12

Cortés Rodas, F. (2011). El contrato social liberal: John Locke. Co-herencia, 7(13), 99-132. 
Cortés Rodas, F. (2017). El lugar político de la justicia y la verdad en la justicia transicional en Colombia. Revista Estudios Políticos Universidad de Antioquia, (50). https://doi.org/10.17533/udea.espo.n50a12

Corte Suprema de Justicia de Colombia. (2019). Corte Suprema dicta orden captura nacional e internacional contra "Jesús Santrich". Recuperado de https:// cortesuprema.gov.co/corte/index.php/2019/07/09/corte-suprema-ordenacaptura-contra-seuxis-paucias-hernandez-solarte/

Cracogna, D. (1984). Revolución y resistencia a la opresión en la doctrina de la iglesia. Revista Facultad de Derecho y Ciencias Políticas, (64), 167-190.

Cury Urzúa, E. (1994). Derecho Penal. Parte General (vol. II). Santiago de Chile: Jurídica de Chile.

De la Mora, R. (2005). Breve historia del pensamiento político. De Platón a Rawls. México: Universidad de Colima.

Delgado, J., \& Carnevali, R. (2020). El rol del juez penal en los acuerdos reparatorios: soluciones alternativas efectivas. Política criminal, 15(29), 1-24. https://doi.org/10.4067/s0718-33992020000100001

Diaz Pantoja, J. S. (2019). La aleatoriedad de la condición de víctimas y/o victimarios de la infancia y adolescencia en el conflicto armado colombiano. Revista CES Derecho, 10(2), 566-590. https://doi.org/10.21615/cesder.10.2.2

Dohna, A. G. (1958). La Estructura de la teoría del delito (trad. C. Fontán Balestra y E. Friker, 4ta edición). Buenos Aires: Abeledo Perrot.

Donna, E. A. (2008). Derecho Penal, Parte General (vol. III). Argentina: RubinzalCulzoni.

Duff, A. (2014). Process, Not Punishment: The Importance of Criminal Trials for Transitional and Transnational Justice. Minnesota Legal Studies Research Paper, 14(3), 12-13. https://doi.org/10.2139/ssrn.2387601

Fernández, G. (1995). Culpabilidad y Teoría del Delito. Buenos Aires: B de F.

Figueiredo Dias, J. (2011). Direito penal. Parte general. Questoes fundamentais a doutrina general do crime (vol. I). Portugal: Coimbra Editora.

Furfaro, M. A. (2013). El derecho de resistencia: desobediencia civil o rebelión. Madrid: Académica Española.

Gaitán, A. M. (2019). Injusto penal. Revista Pensamiento Penal. Recuperado de http://www.pensamientopenal.com/doctrina/47370-injusto-penal

García Cavero, P. (2006). Acerca de la función de la pena. Universidad de Piura. Recuperado de http://perso.unifr.ch/derechopenal/assets/files/ articulos/a_20080521_80.pdf

Gargarella, R. (2016). Castigar al prójimo. Por una refundación democrática del derecho penal. Buenos Aires: Siglo XXI.

LA EXCULPACIÓN

COMO CRITERIO

PUNITIVO FRENTE A

DELITOS CONEXOS

A LA REBELIÓN

EN CONTEXTOS

DE CONFLICTO

ARMADO INTERNO:

UNA RELECTURA

DEL QUEHACER DEL

DERECHO PENAL

EN PROCESOS DE

PACIFICACIÓN

EXCULPATION

AS A PUNITIVE

CRITERIA AGAINST

CRIMES RELATED

TO REBELLION

IN CONTEXTS OF

INTERNAL ARMED

CONFLICT: A

REREADING OF

THE CRIMINAL

LAW WORK IN

PACIFICATION

PROCESSES 
Gimbernat Ordeig, E. (1990). El estado de necesidad: un problema de antijuridicidad. En Estudios de Derecho Penal (pp. 218-230). España: Tecnos.

Gimbernat Ordeig, E. (1999). iTiene un futuro la dogmática jurídico-penal? (3ra edición). Madrid: Editorial Estudios de Derecho penal.

Goldschmidt, J. (2010). El estado de necesidad, un problema de la culpabilidad (trad. M. A. Cano). En J. López Barja de Quiroga (ed.), Derecho, derecho penal y proceso I: Problemas fundamentales del derecho (pp. 343-399). España: Marcial Pons.

Gomes, L. F. (2015). Una aproximación al principio de ofensividad como límite de la intervención penal: contribución al estudio del delito en cuanto "hecho ofensivo típico", lesión o peligro concreto de lesión, al bien jurídico penalmente protegido. España: Universidad Complutense de Madrid.

Gómez Horta, R. (2016). La prevención general y especial en el sistema penal y penitenciario colombiano. Summa Iuris, 4(1), 154-169. https://doi. org/10.21501/23394536.2087

Gómez Huilca, G. (2017). Estado de Necesidad Justificante vs. Estado de Necesidad Disculpante y su correcta aplicación en la Legislación Ecuatoriana. Quito: Universidad San Francisco de Quito.

Gómez López, J. O. (2003). Teoría del Delito. Bogotá: Doctrinaria y Ley.

Gómez Velásquez, A. (2016). Perspectivas de la jurisprudencia de la Corte Interamericana de Derechos Humanos en justicia transicional y su aplicabilidad a las actuales negociaciones de paz en Colombia. Eunomía, (9), 147-160.

Guerra Espinosa, R. (2019). Impulso irresistible en el miedo insuperable. Politica criminal, 14(28), 54-94. https://doi.org/10.4067/s0718-33992019000200054

Guerra Espinosa, R. A. (2020). Tolerancia de la imprecisión en el estado de necesidad. Revista CES Derecho, 11(1), 3-27.

Guzmán Dalbora, J. L. (2019). Mentalidad autoritaria, actitudes punitivas y pensamiento penal: un esbozo. Política criminal, 14(27), 606-634. https://doi. org/10.4067/s0718-33992019000100606

Hassemer, W. (1984). Fundamentos del Derecho Penal (trad. F. Muñoz Conde y L. Arroyo Zapatero). Madrid: Bosch.

Hava García, E. (2013). El tipo de injusto del delito imprudente. Un análisis de sus elementos orientado a la práctica. Buenos Aires: Rubinzal-Culzoni.

Henao Castro, A. F. (2006). La teoría postrawlsiana de la desobediencia civil, Estudios Políticos, (28), 63-97.

Hobsbawm, E. J. (2007). Guerra y paz en el siglo XXI. Barcelona: Crítica.

Hormazábal Malarée, H. (2005). Una necesaria revisión del concepto de culpabilidad, Revista Derecho, 18(2), 167-185. https://doi.org/10.4067/s071809502005000200008 
Jakobs, G. (1997). Derecho Penal, Parte General. Madrid: Marcial Pons.

Jakobs, G. (1997). Sociedad, norma, persona en una teoría de un Derecho penal funcional (trad. M. Cancio y F. Bernardo). Bogotá: Centro de Investigaciones de Derecho Penal y Filosofía del Derecho.

Jakobs, G. (2008). El derecho penal como disciplina científica. Navarra: ThomsonCivitas.

Jescheck, H. H., \& Wigend, T. (2002). Tratado de derecho penal. Parte general (trad. M. Olmedo, 5ta edición). España: Comares.

Jiménez de Asúa, L. (2004). Teoría del Delito. México: Ara.

Kaufmann, A. (1997). Filosofía del derecho. Colombia: Universidad Externado de Colombia.

Kaufmann, A. (1999). Filosofía del Derecho. Bogotá: Universidad Externado de Colombia.

Kindhäuser, U. (2009). Die deutsche Strafrechtsdogmatik zwischen Anpassung und Selbstbehauptung - Grenzkontrolle der Kriminalpolitik durch die Dogmatik. Zeitschrift für gesamte Strafrechtswissenschaft (ZStW), 121(4), 954-964. https://doi. org/10.1515/zstw.2009.954

Künsemüller Loebenfelder, C. (2001). Culpabilidad y pena. Santiago de Chile: Jurídica de Chile.

Latorre Iglesias, E. L., Tirado Acero, M., \& Ardila Mora, J. A. (2018). Sistema de responsabilidad penal adolescente en una sociedad transicional: una mirada interdisciplinaria al caso colombiano. Colombia: Universidad Sergio Arboleda.

Linares, G. (1984). El derecho de rebelión, teoría y práctica. Araucaria de Chile, (29), 13-16.

LA EXCULPACIÓN

COMO CRITERIO

PUNITIVO FRENTE A

DELITOS CONEXOS

A LA REBELIÓN

EN CONTEXTOS

DE CONFLICTO

ARMADO INTERNO:

UNA RELECTURA

DEL QUEHACER DEL

DERECHO PENAL

EN PROCESOS DE

PACIFICACIÓN

\section{EXCULPATION}

AS A PUNITIVE

CRITERIA AGAINST

CRIMES RELATED

TO REBELLION

IN CONTEXTS OF

INTERNAL ARMED

CONFLICT: A

REREADING OF

THE CRIMINAL

LAW WORK IN

PACIFICATION

PROCESSES

Locke, J. (2005). Ensayo sobre el gobierno civil. Buenos Aires: Universidad Nacional de Quilmes-Prometeo.

Lucero P., J. E. (2012). Cara o sello. La decisión crucial en la justicia transicional. Saarbrücken: EAE.

Lucero P., J. E. (2015). Desobediencia civil. Cuestión de tradiciones jurídicas o de composiciones y desestructuraciones sociales. Revista Científica Codex, 1(1), $107-131$.

Luzón Peña, D. (2012). Lecciones de Derecho Penal. Parte General (2da edición). Valencia: Tirant Blanch.

Luzón Peña, D. M. (2016). Lecciones de Derecho Penal. Parte General. Madrid: Tirant Lo Blanch.

Maier, J. (1978). Política criminal. Derecho Penal y Procesal Penal. Doctrina PenalDepalma, 1(1-4). 
Marinucci, G., \& Dolcini, E. (2009). Manuale di diritto penale. Parte generale. Italia: Giuffrè Editore.

Martínez Arancon, A., Casas Santero, E., \& Casas Santero, I. (2014). Ideas y formas políticas. De la antigüedad al renacimiento. Madrid: Universidad Nacional de Educación a Distancia.

Maurach, R., \& Zipf, H. (1994). Derecho penal. Parte general. Argentina: Astrea.

Mir Puig, S. (1983). Problemas del estado de necesidad en el art. 8.7 del Código Penal. En Estudios Jurídicos en Honor del Profesor Octavio Pérez Vitoria (vol. I, pp. 501-520). España: Bosch.

Mir Puig, S. (1998). Derecho penal parte general (5ta edición). Barcelona: Tecfoto.

Mir Puig, S. (2016). Derecho Penal, Parte General (10ma edición). Barcelona: Reppertor.

Morselli, E. (1995). Neorretribucionismo y prevención general integradora en la teoría de la pena. Anuario de derecho penal y ciencias penales, 48(1), 265-274.

Muñoz Conde, F. (1981). Introducción. En C. Roxin, Culpabilidad y prevención en Derecho penal (trad. F. Muñoz Conde). Madrid: Reus.

Muñoz Conde, F. (1985). Derecho penal y control social. Jerez: Fundación Universitaria de Jerez.

Muñoz Conde, F. (2017). Estado de necesidad y tortura. En 40avo Cursos de Especialización en Derecho Universidad de Salamanca. Recuperado de https://www. youtube.com/watch?v $=$ SJIHZJMTbc4

Muñoz Hernández, L. A. (2016). Prueba, verdad, verifobia en la justicia transicional. Tensión derecho, paz y justicia - Colombia, ley 975/2005. Revista Jurídicas CUC, 12 (1), 215-238. https://doi.org/10.17981/juridcuc.12.1.2016.12

Nazir Lleneris, I. P. (2015). Delitos conexos al delito político susceptibles de amnistía e indulto en Colombia análisis jurisprudencial y doctrinal. Colombia: Universidad de Cartagena.

Negro Pavón, D. (1992). Derecho de resistencia y tiranía. Anales del Seminario de Metafísica, Homenaje a Sergio Rábade (número extra 1992), 683-707.

Ovalle Bazán, M. I. (2019). La dignidad humana como límite al ius puniendi. La jurisprudencia del Tribunal Constitucional de Chile. Dikaion, 28(1), 35-68. https://doi.org/10.5294/dika.2019.28.1.2

Pawlik, M. (2013). El estado de necesidad defensivo justificante dentro del sistema de los derechos de necesidad. Revista Derecho Penal y Criminología, XXXIV(96), 13-29.

Pérez, L. (1986). Derecho Penal. Partes General y Especial (vol. III). Bogotá: Temis.

Piña Rochefort, J. I. (2019). La solidaridad como fuente de deberes. Elementos para su incardinación en el sistema jurídico penal. Política criminal, 14(27), 242-276. https://doi.org/10.4067/s0718-33992019000100242 
Pouillon, J. (1969). Problemas del Estructuralismo (2da edición). Buenos Aires: Siglo XXI.

Quinteros Olivares, G. (2010). Parte General del Derecho Penal (4ta edición). Pamplona: Aranzadi.

Ramírez Contreras, L. F. (2016). Delitos por omisión y atribución de autoría por omisión, como componentes esenciales de la teoría del delito. España: Universidad Nacional de Educación a Distancia.

Ramírez Echeverri, J. D. (2010). Thomas Hobbes y el Estado absoluto: del Estado de razón al Estado de terror. Colombia: Universidad de Antioquia.

Redondo, M. C. (2006). Sobre la completitud de los sistemas jurídicos. Revista Análisis Filosófico, 26(2), 294-324.

Rettig Espinoza, M. A. (2009). Desarrollo previsible de la relación entre la antijuridicidad y la culpabilidad. Revista de derecho, XXII(2), 185-203. https://doi. org/10.4067/s0718-09502009000200010

Rodríguez Ferrández, S. (2017). Neurociencias y derecho penal: una visión compatibilista actualizada. Revista Justiça e Sistema Criminal, 9(17), 111-134.

Roxin, C. (1997). Derecho penal. Parte general (vol. I) (trad. D. Luzón, M. Díaz y V. Remesal). España: Civitas.

Roxín, C. (2002). Política criminal y sistema del derecho penal. Buenos Aires: Hammurabi.

Roxín, C. (2006). Derecho penal, parte general. Madrid: Civitas.

Roxin, C. (2008). Derecho Penal, Parte General (vol. I). España: Thomson-Civitas

Rúa Delgado, C. F. (2020). Justicia transicional: en la posmodernidad del derecho. Revista Ius et Praxis, 26(1), 124-148. https://doi.org/10.4067/s071800122020000100124

Schünemann, B. (1991). Introducción al razonamiento sistémico en Derecho Penal. En B. Schünemann y J. M. Silva Sánchez (coords.), El sistema moderno del derecho penal: cuestiones fundamentales. Estudios en honor de Claus Roxín en 50 aniversario (pp. 31-93). España: Tecnos.

Schünemann, B. (1991-b). La función del principio de culpabilidad en el derecho penal preventivo. En B. Schünemann y J. M. Silva Sánchez (coords.), El sistema moderno del derecho penal: cuestiones fundamentales. Estudios en honor de Claus Roxín en 50ํaniversario (pp. 147-178). España: Tecnos.

Schurmann, M. (2019). iEs científico el discurso elaborado por la dogmática jurídica? Una defensa de la pretensión de racionalidad del discurso dogmático elaborado por la ciencia del derecho penal. Política criminal, 14(27), 549-598. https://doi.org/10.4067/s0718-33992019000100549

Silva Sánchez, J. M. (1992). Aproximación al derecho penal contemporáneo. Barcelona: Bosch.

LA EXCULPACIÓN

COMO CRITERIO

PUNITIVO FRENTE A

DELITOS CONEXOS

A LA REBELIÓN

EN CONTEXTOS

DE CONFLICTO

ARMADO INTERNO:

UNA RELECTURA

DEL QUEHACER DEL

DERECHO PENAL

EN PROCESOS DE

PACIFICACIÓN

\section{EXCULPATION}

AS A PUNITIVE

CRITERIA AGAINST

CRIMES RELATED

TO REBELLION

IN CONTEXTS OF

INTERNAL ARMED

CONFLICT: A

REREADING OF

THE CRIMINAL

LAW WORK IN

PACIFICATION

PROCESSES 
Squella, A. (2010). Algunas concepciones de la justicia. Anales de la Cátedra Francisco Suárez, 44, 175-216.

Squella, A. (2014). Introducción al Derecho (vol. I). Santiago de Chile: Thomson Reuters.

Stevens, F., Poirier, P., \& Van Den Berg, P. (2008). Constitutions of the world from the late 18th century to the middle of the 19th century. Berlín: K. G. Saur.

Suñez Tejera, Y. (2013). Valoraciones teórico jurídicas en torno a la eximente del miedo insuperable. Revista Caribeña de Ciencias Sociales, (mayo), 1-23.

Travesí, F., \& Rivera, H. (2016). Delito político, amnistías e indultos: Alcances y desafios. En International Center of Transitional Justice (ICTJ). Recuperado de https://www.ictj.org/es/publication/colombia-delito-politico-amnistia-indulto

Trejos Rosero, L. F. (2008). Naturaleza, actores y características del conflicto armado colombiano: una mirada desde el derecho internacional humanitario. Revista Encrucijada Americana, 2(2), 1-35.

Trejos Rosero, L. F. (2011). El derecho internacional humanitario en el conflicto armado colombiano. Propuestas para su aplicación. Revista Derecho y Humanidades, (18), 131-143.

Uribe Álvarez, R. (2012). Sobre la posición sistemática del estado de necesidad y sus problemas dogmáticos. Colombia: Universidad EAFIT.

Velásquez V., F. (1993). La Culpabilidad y el Principio de Culpabilidad. Revista de Derecho y Ciencias Politicas, 50, 283-310.

Vera, J. S. (2019). Legítima defensa y elección del medio menos lesivo. Revista Ius et Praxis, 25 (2), 261-298. https://doi.org/10.4067/s0718-00122019000200261

Vives Antón, T., \& Cobos del Rosal, M. (1999). Derecho Penal, Parte General. Valencia: Tirant Lo Banch.

Waldron, J. (2004). Torture and Positive Law: Jurisprudence for the White House. General Aspects of Law (GALA), Seminarian de la University of California, 1-66. Recuperado de https://escholarship.org/uc/item/23d27577

Welzel, H. (1964). El nuevo sistema del Derecho Penal. Una introducción a la doctrina de la acción finalista. Barcelona: Ariel.

Welzel, H. (1968). La doctrina de la acción finalista, hoy. Anuario de Derecho Penal y Ciencias Penales, 21 (2), 221-230.

Welzel, H. (1980). La teoría de la acción finalista. Chile: Ediciones Jurídicas del Sur.

Wessels, J. (1980). Derecho Penal, Parte General. Buenos Aires: Depalma.

Wilenmann von Bernath, J. (2016). Imponderabilidad de la vida humana y situaciones trágicas de necesidad. INDRET - Revista para el análisis del derecho, (1), $1-54$. 
Wilenmann, J. (2014). El fundamento del estado de necesidad justificante en el derecho penal chileno. Revista Derecho Universidad de Valdivia, 27(1), 213-244. https://doi.org/10.4067/s0718-09502014000100010

Zaffaroni, E. R. (2012). Crímenes de masa (2da edición). México: Madres de Plaza de Mayo.

Zaffaroni, E. R. (2017). La protesta social y el derecho penal. En E. R. Zaffaroni, M. Bailone y R. Mavila León, Dogmática Penal y Criminología Cautelar. Una introducción a la criminología cautelar con especial énfasis en la criminología mediática (pp. 83-88). Perú: Ideas.

Zaffaroni, E. R. (2018). Estructura básica del derecho penal. Recuperado de http:// www.matiasbailone.com/dip/Zaffaroni\%20-\%20Estructura\%20Basica\%20 de\%20Derecho\%20Penal.pdf

Zárate Conde, A., \& González, E. (2015). Derecho Penal, Parte General. España: La Ley.

Jurisprudencia, normativa y otros documentos legales Caso Almonacid Arellano vs. Chile, Caso contencioso, Serie CN 154 (Corte IDH, 26 de septiembre de 2006). Recuperado de https://www.corteidh.or.cr/docs/casos/ articulos/seriec_154_esp.pdf

Caso Barrios Altos vs. Perú, Caso contencioso, Serie C No 75 (Corte IDH, 14 de marzo de 2001). Recuperado de https://www.corteidh.or.cr/docs/casos/articulos/ Seriec_75_esp.pdf

Caso Gelman vs. Uruguay, Caso contencioso, Serie C N 221 (Corte IDH, 24 de febrero de 2011). Recuperado de https://www.corteidh.or.cr/docs/casos/articulos/ seriec_221_esp1.pdf

Caso Gomes Lund y otros vs. Brasil. Caso contencioso, Serie CN²19 (Corte IDH, 24 de noviembre de 2010). Recuperado de https://www.corteidh.or.cr/docs/casos/ articulos/seriec_219_esp.pdf

Caso Masacres de El Mozote y Lugares Aledaños vs. El Salvador, Caso contencioso, Serie C N 252 (Corte IDH, 25 de octubre de 2012). Recuperado de https:// corteidh.or.cr/docs/casos/articulos/seriec_252_esp.pdf

Código Penal Alemán (trad. C. López Diaz) (1999). Recuperado de http://perso. unifr.ch/derechopenal/assets/files/legislacion/_20080616_02.pdf

Masacre de Santo Domingo vs. Colombia, Caso contencioso, Serie CN 259 (Corte IDH, 30 de noviembre de 2012). Recuperado de https://www.corteidh.or.cr/docs/ casos/articulos/seriec_259_esp.pdf

Sentencia C-577 (Corte Constitucional [Colombia], 2014).

LA EXCULPACIÓN

COMO CRITERIO

PUNITIVO FRENTE A

DELITOS CONEXOS

A LA REBELIÓN

EN CONTEXTOS

DE CONFLICTO

ARMADO INTERNO:

UNA RELECTURA

DEL QUEHACER DEL

DERECHO PENAL

EN PROCESOS DE

PACIFICACIÓN

EXCULPATION

AS A PUNITIVE

CRITERIA AGAINST

CRIMES RELATED

TO REBELLION

IN CONTEXTS OF

INTERNAL ARMED

CONFLICT: A

REREADING OF

THE CRIMINAL

LAW WORK IN

PACIFICATION

PROCESSES 